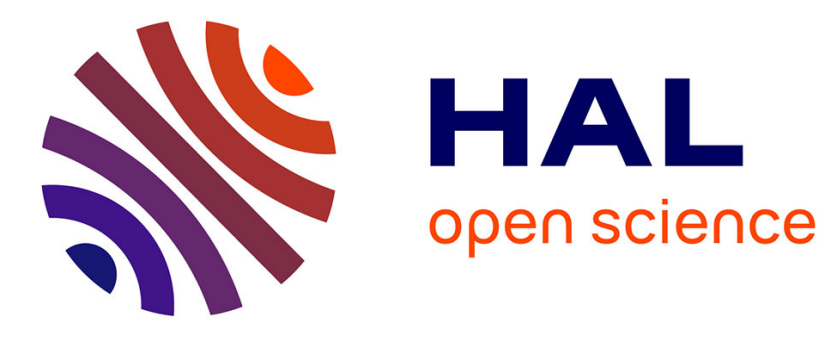

\title{
Hemp-based materials for metal removal
}

Nadia Morin-Crini, Sonia Loiacono, Vincent Placet, Giangiacomo Torri, Corina Bradu, Mirjana Kostić, Cesare Cosentino, Gilles Chanet, Bernard Martel, Eric Lichtfouse, et al.

\section{- To cite this version:}

Nadia Morin-Crini, Sonia Loiacono, Vincent Placet, Giangiacomo Torri, Corina Bradu, et al.. Hempbased materials for metal removal. Green Adsorbents for Pollutant Removal, 19, Springer Nature, pp.1-34, 2018, Environmental Chemistry for a Sustainable World, 978-3-319-92162-4. 10.1007/978-3319-92162-4_1. hal-02065613

\section{HAL Id: hal-02065613 https://hal.science/hal-02065613}

Submitted on 12 Mar 2019

HAL is a multi-disciplinary open access archive for the deposit and dissemination of scientific research documents, whether they are published or not. The documents may come from teaching and research institutions in France or abroad, or from public or private research centers.
L'archive ouverte pluridisciplinaire HAL, est destinée au dépôt et à la diffusion de documents scientifiques de niveau recherche, publiés ou non, émanant des établissements d'enseignement et de recherche français ou étrangers, des laboratoires publics ou privés. 


\title{
Hemp-Based Materials for Metal Removal
}

\author{
Nadia Morin-Crini, Sonia Loiacono, Vincent Placet, Giangiacomo Torri, \\ Corina Bradu, Mirjana Kostić, Cesare Cosentino, Gilles Chanet, \\ Bernard Martel, Eric Lichtfouse, and Grégorio Crini
}

\section{Contents}

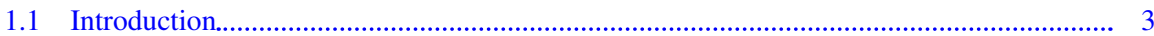

1.2 Hemp, an Interesting Raw Material.............................................................................. 5

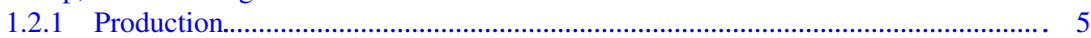

1.2.2 Types of Hemp-Based Products and Applications....................................................... 7

1.3 A Novel Application of Hemp-Based Material for Removal of Metals:

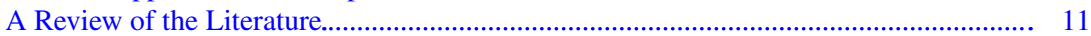

1.3.1 Biosorption, a Useful Decontamination Process for Contaminant Removal........ 11

1.3.2 Hemp-Based Materials as Biosorbents................................................................. 14

1.3.3 Composite Materials.............................................................................................. 20

1.3.4 Activated Carbons from Hemp.............................................................................. 20

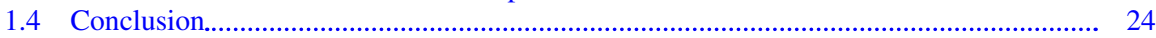

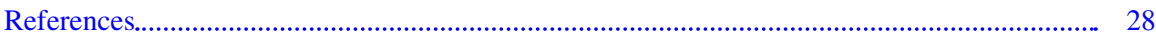

\footnotetext{
N. Morin-Crini $(\bowtie) \cdot$ S. Loiacono $\cdot$ G. Crini

Laboratoire Chrono-Environment, UMR 6249, UFR Sciences et Techniques,

Université Bourgogne Franche-Comté, Besançon, France

e-mail: gregorio.crini@univ-fcomte.fr; sonia.loiacono@univ-fcomte.fr;

nadia.crini@univ-fcomte.fr
}

\section{Placet}

FEMTO-ST Institute, CNRS/UFC/ENSMM/UTBM, Department of Applied Mechanics,

Bourgogne Franche-Comté University, Besançon, France

e-mail: vincent.placet@univ-fcomte.fr

G. Torri $\cdot$ C. Cosentino

Istituto di Chimica e Biochimica G. Ronzoni, Milan, Italy

e-mail: cosentino@ ronzoni.it; torri@ ronzoni.it

C. Bradu

Research Center for Environmental Protection and Waste Management,

University of Bucharest, Bucharest, Romania

e-mail: corina.bradu@g.unibuc.ro

M. Kostić

Faculty of Technology and Metallurgy, University of Belgrade, Belgrade, Serbia

e-mail: kostic@tmf.bg.ac.rs 


\begin{abstract}
With the increasing focus on renewable materials and sustainability issues, the development of non-conventional materials from natural resources and possessing complexing properties is currently an area of extensive research due to their potential applications in biosorption processes for pollutant removal. Among them, the hemp plant, an annual high yielding industrial crop grown for its fibres and seeds, is one of the most promising material for biosorption of metal ions from diluted waste streams. In this chapter, an extensive list of hemp-based biosorbent literature has been compiled and discussed. After a brief description of hemp and its properties and applications, the chapter gives a general overview of liquid-solid biosorption processes for metal removal from aqueous solutions onto hemp-based materials.
\end{abstract}

\title{
Abbreviations
}

AC activated carbons

CAC commercial activated carbons

DSC differential scanning calorimetry

EDX energy-disperse X-ray spectroscopy

FT-IR Fourier transform infra-red spectrophotometry

MFA microfibrils angle

NMR nuclear magnetic spectroscopy

SEM scanning electron microscopy

SPE solid-phase extraction

TGA thermogravimetric analysis

THC delta-9-tetrahydrocannabinol

XPS X-ray photoelectron spectroscopy

$\Delta \mathrm{G} \quad$ Gibbs free energy change

$\Delta \mathrm{H} \quad$ enthalpy change

$\Delta \mathrm{S} \quad$ entropy change

G. Chanet

Eurochanve, Arc-les-Gray, France

e-mail: gilles.chanet@interval.coop

B. Martel

University of Lille, CNRS, INRA, ENSCL, UMR 8207, UMET - Unité Matériaux et

Transformations, Lille, France

e-mail: bernard.martel@univ-lille1.fr

E. Lichtfouse

CEREGE - Centre européen de recherche et d'enseignement des géosciences de l'environnement, Université Aix-Marseille, Collège de France, CNRS, INRA, IRD, Europôle Méditerranéen de l'Arbois, Aix-en-Provence, France

e-mail: eric.lichtfouse@inra.fr 


\subsection{Introduction}

Many wastewaters contain significant levels of organic and mineral contaminants which are toxic or otherwise undesirable because they create, in particular, odor, bad taste and color. Amongst the numerous techniques of contaminant removal, liquid-solid adsorption is the procedure of choice as it can be used to efficiently remove different types of contaminants (Manes 1998; Cooney 1999; Liu and Liptak 2000; Dąbrowski 2001; Yang 2003; Crini and Badot 2008; Sharma and Sanghi 2012). Furthermore, adsorption can produce high quality water while also being a process that is both technologically simple and economically feasible. So, adsorption processes from aqueous solutions are important techniques in water purification, wastewater decontamination, and many other areas such as recovery and separation applications.

Carbons are one of the oldest and most widely used adsorbents in industry (Manes 1998). Indeed, due to their great capacity to adsorb contaminants, commercial activated carbon (CAC) are the most effective adsorbents, and if the adsorption system is properly designed they give a good-quality output, with concentrations under the legal limits for discharge waters. This capacity is mainly due to their structural characteristics and their porous texture which gives them a large surface area, and their chemical nature which can be easily modified by chemical treatment in order to improve their properties. The processes that use these usual adsorbents are often carried out in a batch mode, by adding activated carbon (AC) to a vessel containing the contaminated solution, or by feeding the solution continuously through a packed bed of carbon. Adsorption processes using AC are also interesting because of convenience, easy operation, and their simplicity of design (Manes 1998; Radovic et al. 2000).

However, although these commercial materials are preferred conventional adsorbents for contaminant removal, their widespread industrial use is restricted due to high cost (Crini 2005; Kyzas and Kostoglou 2014). As such, alternative nonconventional adsorbents including products and by-products of biological and agricultural origin, and from forest industries were proposed, studied and employed as inexpensive and efficient adsorbents - in this case called biosorbents due to their natural origin and property to bind and concentrate metal ions from aqueous solutions (McKay 1996; Volesky 2004; Blackburn 2004; Crini 2006; Oliveira and Franca 2008; Crini and Badot 2010; Rezić 2013; Michalak et al. 2013; Vijayaraghavan and Balasubramanian 2015; Sharma 2015; Muya et al. 2016; Okenicova et al. 2016; Khalaf 2016; Zhao et al. 2016).

Indeed, the past three decades have shown an explosion in the development of new materials proposed as biosorbents for metal removal in biosorption-oriented processes using various contacting systems. These include living organisms (e.g. algae, bacteria, fungi, and yeasts) and dead biomass (e.g. bark, sawdust, peat, natural fibres such as cotton and flax, plants, and other organic substances such as biopolymers or polysaccharides). Polysaccharides include starch, cellulose, alginate and chitin and their derived products such as chitosan and cyclodextrins. These 
Table 1.1 Examples of biosorbents used in biosorption-oriented processes for metal removal from water/wastewater with special attention to polysaccharide-based biosorbents (selected reviews)

\begin{tabular}{|c|c|}
\hline Biosorbent & Reference(s) \\
\hline $\begin{array}{l}\text { Agricultural wastes } \\
\text { (sawdust, bark, peat, } \\
\text { coffee, date pits...) }\end{array}$ & $\begin{array}{l}\text { Novoselova and Sirotkina (2008); Crini and Badot (2010); Dulman and } \\
\text { Cucu-Man (2010); Fomina and Gadd (2014); Kyzas and Kostoglou } \\
\text { (2014); Westholm et al. (2014); Suba and Rathika (2016); Tapia-Orozco } \\
\text { et al. (2016); Ahmed (2016); De Gisi et al. (2016); Raval et al. (2016); } \\
\text { Anastopoulos et al. (2017a) }\end{array}$ \\
\hline Algae (seaweeds) & $\begin{array}{l}\text { Fomina and Gadd (2014); He and Chen (2014); Kumar et al. (2015); } \\
\text { Dabbagh et al. (2016) }\end{array}$ \\
\hline Alginate & Nastaj and Przewlocka (2014); Vandenbossche et al. (2015) \\
\hline Biomass & Mudhoo et al. (2012); Gorska et al. (2014) \\
\hline $\begin{array}{l}\text { Cellulose and } \\
\text { derivatives }\end{array}$ & $\begin{array}{l}\text { Hubbe et al. (2011); Mudhoo et al. (2012); Rezić (2013); Vandenbossche } \\
\text { et al. (2015); Salman et al. (2015); Tran et al. (2015); Ummartyotin and } \\
\text { Pechyen (2016); Kumar et al. (2017) }\end{array}$ \\
\hline $\begin{array}{l}\text { Chitin, chitosan and } \\
\text { derivatives }\end{array}$ & $\begin{array}{l}\text { Mudhoo et al. (2012); Westholm et al. (2014); Tran et al. (2015); } \\
\text { Ummartyotin and Pechyen (2016); Zhang et al. (2016); Anastopoulos } \\
\text { et al. (2017b) }\end{array}$ \\
\hline Composts & Anastopoulos and Kyzas (2015) \\
\hline Eggshell & Ummartyotin and Pechyen (2016) \\
\hline $\begin{array}{l}\text { Extracellular } \\
\text { polymeric substances }\end{array}$ & More et al. (2014); Li and Yu (2014) \\
\hline $\begin{array}{l}\text { Microbial materials } \\
\text { (fungi, bacteria, } \\
\text { yeasts...) }\end{array}$ & $\begin{array}{l}\text { Dhankhar and Hooda (2011); Srivastava et al. (2015); Shakya et al. } \\
\text { (2016); Ayangbenro and Babalola (2017) }\end{array}$ \\
\hline Pectin & Vandenbossche et al. (2015); Zhao and Zhou (2016) \\
\hline Plant materials & Fomina and Gadd (2014); Srivastava et al. (2015) \\
\hline Starch and derivatives & $\begin{array}{l}\text { Crini and Badot (2010); Morin-Crini and Crini (2013); Vandenbossche } \\
\text { et al. (2015); Sharma (2015); Haroon et al. (2016) }\end{array}$ \\
\hline
\end{tabular}

materials are interesting due to the fact that they are abundant in nature, available in large quantities, inexpensive, and may have potential as biosorbent materials due to their physicochemical characteristics and particular structure (Volesky 2004; Blackburn 2004; Crini 2005, 2006). Abundant data can be found in the literature. Table 1.1 reports some examples of materials used in the biosorption process with special attention to polysaccharide-based adsorbents.

Actually, numerous works are being conducted on the use of hemp-based materials as biosorbents. Hemp is a fast growing, annual herbaceous (Fig. 1.1) and multipurpose plant. In particular, its bast fibres are natural, cheap, strong, stiff and lightweight, and have been not only identified as attractive reinforcements for composites (thermoplastic polymers...) and material for wool insulation but also as useful chelating materials.

An analysis of the Web of Science database reveals that 104 publications containing both the keywords 'hemp' and 'metal' in the topic category have been published from 2002 to 2016. Figure 1.2 clearly shows an increase of citations. Each publication has been cited 15.98 times on the average. Overall this finding shows a growing research interest. To the best of our literature review, this chapter is the first pub- 
b)

a)
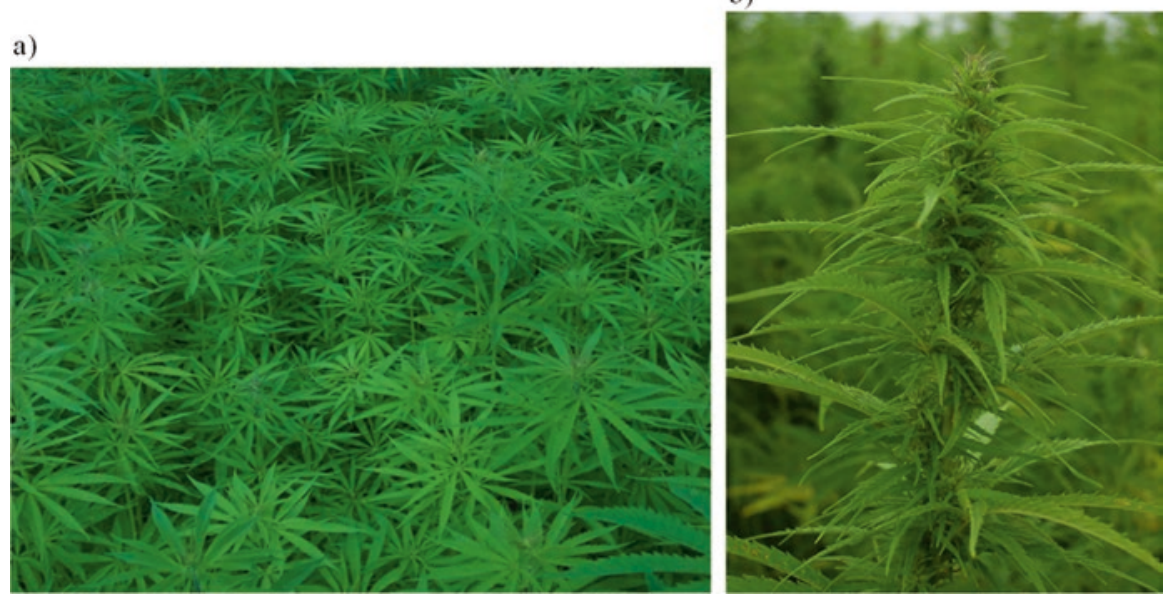

Fig. 1.1 Hemp field (a) and dioecious male plant (b)

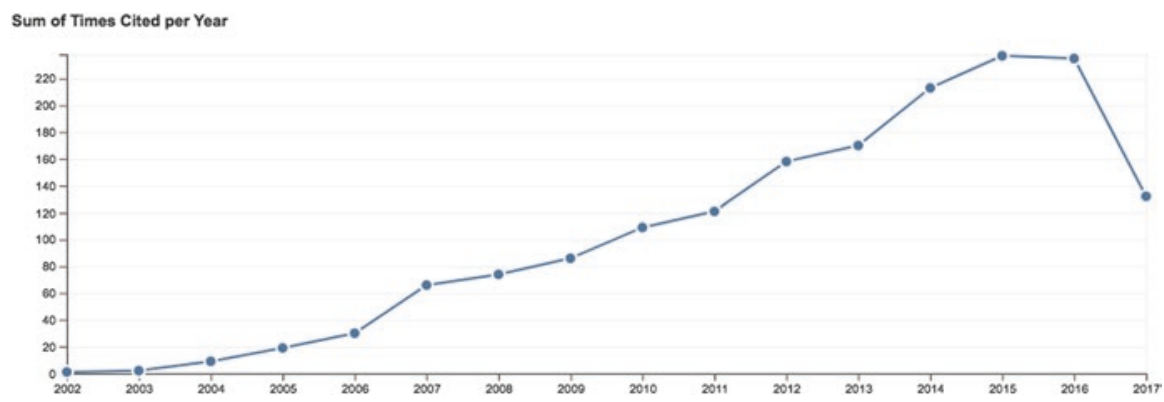

Fig. 1.2 Citations of the 104 publications on hemp and metal in the Web of Science Core Collection, published from 2002 to 2017 (the analysis was performed using the expression 'hemp AND metal' in the topic category, on July 4, 2017)

lished review on the potential use of hemp-based materials in water and wastewater treatment. After a brief description of hemp and its properties and applications, the chapter gives a general overview of liquid-solid biosorption processes for metal removal from aqueous solutions onto hemp-based materials. For this, an extensive list of hemp-based biosorbent literature has been compiled and discussed.

\subsection{Hemp, an Interesting Raw Material}

\subsubsection{Production}

Hemp is one of the oldest domesticated crops known to man. Hemp fibres were used for textiles and cordages, and the seeds as nutrition for thousands of years. Hemp originated from Asia and was already cultivated 4500 years ago in China (Ranalli 
1999; Bouloc 2013). The first copies of the Bible were made of hemp paper (Ranalli and Venturi 2004). Hemp bast fibres were the principal natural fibres used for maritime ropes and sails for centuries. Oils from hemp seeds were also used for a wide range of purposes, from cooking to cosmetics. It is estimated that hemp was imported to Europe by nomads in the sixteenth century (Bouloc 2013). In the middle of nineteenth century, hemp cultivation decreased with disappearance of the sailing navy and competition from other natural fibres (cotton, jute...) for textile applications, and later due to intensive development of synthetic fibres (Milanovic et al. 2012). In the 1930s, cultivation was forbidden in the vast majority of Western countries due to the fact that hemp and marijuana come from the same genus and species plant (Cannabis sativa L.), and this introduced a lot of confusion and social and political controversies. In the last two decades, the increasing consideration of natural resources and energy conservation has renewed the interest on hemp as a "new" low-cost, ecological, biodegradable, sustainable, recyclable, and multipurpose biomaterial (Shahzad 2012; Bouloc 2013; Bono et al. 2015).

Hemp is a dicotyledonous plant from the order of Rosales, from the family of Cannabaceae, genus Cannabis (Bouloc 2013). Hemp - also called industrial hemp refers to the non-psychoactive varieties of Cannabis sativa $\mathrm{L}$. Industrial hemp is often incorrectly associated with hemp for narcotics due to the fact that the psychoactive ingredient, delta-9-tetrahydrocannabinol (THC), found in hashish, is present in all hemp varieties to some extent. European regulations limit THC content to $0.3 \%$ in industrial hemp. In Canada, the THC limit is 1\%. Marijuana (called medical cannabis) contains about 10-30\% of THC level (Bouloc 2013; Pacaphol and Aht-Ong 2017).

Hemp is an annual high yielding industrial crop grown for its fibres and seeds. This plant is being mainly cultivated in Europe, Canada and China (the largest supplier in the world). France is the top European producer of hemp with an area of cultivation around 12,000 ha. Other important producing countries are Romania, Italy, Poland and Hungary (Amaducci 2005; Bouloc 2013; Salentijn et al. 2015). Since hemp is one of the most efficient plants known for its ability to utilize sunlight and capture large quantities of $\mathrm{CO}_{2}$ to photosynthesize, with an annual growth up to $5 \mathrm{~m}$ in height, production of hemp fiber is experiencing a renaissance again. Currently, hemp is the subject of a European Union subsidy for non-food agriculture, and a considerable initiative for its further development in Europe is underway (Ranalli and Venturi 2004; Faruk et al. 2012; Bouloc 2013).

Hemp is considered as an excellent crop for sustainable agriculture. Selection of a hemp cultivar and the manner of sowing depend on the purpose of the material produced (fibre or seed). Indeed, there are mainly two groups of Cannabis varieties being cultivated today: varieties primarily cultivated for their fibre (called industrial hemp) used for example for construction material, clothing or animal related purposes, and varieties grown for seed from which oil is extracted (breeding, or food); hemp can also be cultivated as dual-purpose crop that implies that both fibres and seeds can be processed (Bouloc 2013).

As a biodegradable plant which needs no irrigation or phytosanitary treatments, hemp is excellent as a crop rotation leader to alternate with crops such as beets or grains (Amaducci and Gusovious 2010). Furthermore, hemp can also be an excellent 
predecessor in crop rotation, in particular before winter cereals such as wheat. Hemp is more environmentally friendly than traditional crops. After sowing, cultivation is not difficult. The crop requires only rarely the use of plant protection products and hemp requires low fertilization. Easily adaptable to all types of soil and well-adapted to temperate climates such as in Europe, hemp is appreciated by organic growers not only for its ease of production but also for its rapid growth (120-150 days cropping cycle). Fibre hemp may yield up to $25 \mathrm{t}$ above ground dry matter per ha (20 t stem dry matter per ha) which may contain maximum $12 \mathrm{t} / \mathrm{ha}$ of cellulose, depending on the genetics (e.g. varieties), cultivation practices, climate and environmental conditions (Bouloc 2013; Ingrao et al. 2015). Hemp also leaves an excellent quality, weed-free soil at the end of each season. Hemp detoxifies the soil and prevents soil erosion. Finally, hemp cultivation is a vector of development for local agricultural resources in emerging countries and an industrial output for crops in developed countries (Le Troëdec et al. 2011).

\subsubsection{Types of Hemp-Based Products and Applications}

Hemp is an interesting raw material for its very low-cost, abundancy, renewable character, particular chemical composition of its fibres including moisture content, macromolecular network with numerous hydroxyl groups capable of forming intra- and intermolecular bonds, and specific physical (low density), mechanical, thermal, acoustic and aseptic properties (Păduraru and Tofan 2008; Bouloc 2013; Amaducci et al. 2015). Hemp fibres are also classified as eco-friendly material and good candidates as a (partial) substitute for synthetic fibres such as glass, carbon or metallic fibres.

Cannabis sativa $\mathrm{L}$. is the source of two types of natural fibres: bast fibres (fibrous form) and woody core fibres, called hurds or shives (granular form). Its cultivation also provides seeds for oil production. Hemp stem consists of approximately $20-40 \%$ of bast fibres and 60-80\% of hurds (Stevulova et al. 2014). The outside of the stem is covered with bark (called epidermis). Inside the stems are bast fibres and the woody core. The separation of the bast fibre is carried out through defiberization or decortication (breaking the woody core of the stems into short pieces and separation of bast fibre from the hurds) using specialized machineries. The hemp fibres are situated in the bast of the hemp plant. The byproduct of the hemp stem obtained after the industrial defiberization process is called chenevotte (constituted from the xylem tissue of the stem, i.e. the shives).

Technical (multi-cellular) fibres, composed of elementary fiber bundles obtained by primary processing of stalks are characterized with heterogeneous chemical composition and fairly complicated structure. The main constituents are cellulose, hemicellulose and lignin (Table 1.2), while minor components such as pectin and waxes are regarded as surface impurities (Placet et al. 2014, 2017). As member of the bast fibre family, hemp contains over $75 \%$ of cellulose and less than 10 to $12 \%$ of lignin (compared with $60 \%$ and $30 \%$ respectively for wood). The bast fibres contain higher amounts of cellulose than the hurds (Table 1.2). 
Table 1.2 Chemical composition of hemp fibres in wt \% (Placet et al. 2017)

\begin{tabular}{l|l|l}
\hline Component & $\begin{array}{l}\text { Bast } \\
\text { fibres }\end{array}$ & Hurds \\
\hline Cellulose & $57-77 \%$ & $40-48 \%$ \\
\hline Hemicellulose & $9-14 \%$ & $18-24 \%$ \\
\hline Lignin & $5-9 \%$ & $21-24 \%$ \\
\hline
\end{tabular}
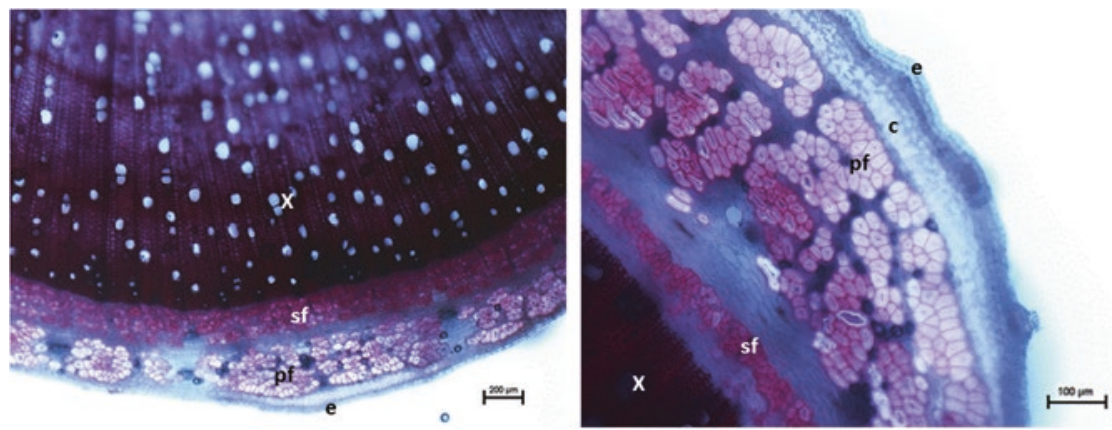

Fig. 1.3 Hemp (Cannabis sativa) stem cross sections - Microscopic observations of fresh transverse sections at two different magnifications after cytochemical staining using the Wiesner reagent (phloroglucinom- $\mathrm{HCl}$ ) that gives a purple-red coloration to lignin $(X$ xylem, $p f$ primary fibres, $s f$ secondary fibres, $c$ collenchyma, $e$ epidermis)

Their structure is complex. Indeed, hemp fibres are very heterogeneous and can be considered themselves as a composite material comprising three different parts (Le Troëdec et al. 2011). From the outer to the inner part, fibres consist of a middle lamella, a primary, a secondary and a tertiary cell wall, build up around an opening, the lumen. The bast fibres are joined together by the middle lamella, mainly composed of pectin (macromolecules of galacturonic acid) encrusted with lignin that hold fibres together into a bundle. Next to the middle lamella, the primary cell wall consists of disorganized arrangements of cellulose fibrils embedded in an organic matrix of hemicelluloses, lignin and proteins. The secondary cell wall consists of three layers of cellulose fibrils with different axial orientation that are bound by hemicelluloses. Each fibre bundle consists of single (elementary) fibres. There are two types of fibres with approximately the same diameter: (i) the useful primary fibres (5-55 $\mathrm{mm}$ long) and (ii) the short secondary fibres ( $2 \mathrm{~mm}$ long). However, the cell walls of the bast fibres are 5 to 10 times thicker than those of woody fibres. In contrast to the high quality of bast fibres, the hurds is the least valuable part of the plant, chemically close to wood (Stevulova et al. 2014). Figure 1.3 shows microscopic observations of fresh transverse hem stem sections at two different magnifications showing lignin component.

Above mentioned complex structure and heterogeneous chemical composition of hemp fibres are the crucial factors that affect their specific characteristics. On such way, the chemical composition and cell wall microstructure can help to determine properties and end uses of the fibres. For instance, higher cellulose content and low cellulose MFA (microfibrils angle) correlate to high strength and stiffness and 
is ideal for polymer reinforcement. From the other hand, polar and hydrophilic nature of cellulose fibres, mainly as a consequence of their chemical structure, is limiting factor for the extended use of these fibres in composites (Bismarck et al. 2005). In the same time, this hydrophilic character of the fibres positively affects their biosorption properties as it will be discussed.

In plant fibres, water can be held in the form of bound water and free water. Free water can be found as liquid, liquid-vapor mixture or vapor within the fibre lumen. Bound water interacts with the hydrophilic polymers of the fibre wall. It is absorbed into the cell wall by hydrogen bonds on the accessible polar hydroxyl groups, generally termed biosorption sites. The constitutive hydrophilic polymers are classically classed into three types: (i) cellulose, (ii) hemicelluloses and pectins and (iii) lignins.

Cellulose is made of linear chains of glucose aggregated into microfibrils, including highly crystalline parts surrounding by amorphous components (also called paracrystalline cellulose). Even though cellulose has a high hydroxyl group to carbon element $(\mathrm{OH} / \mathrm{C})$ ratio, most of them are inaccessible to water molecules, due to the crystalline organization, and water molecules can gain access only into amorphous cellulose. Hemicelluloses and pectins are predominantly amorphous polysaccharides with high $(\mathrm{OH} / \mathrm{C})$ ratio and highly accessible to water molecules. Lignin is third main type of hydrophilic polymeric constituent. It is an amorphous crosslinked polymer, composed of phenolic units, that occurs in plant fibres with more or less amounts, and which has relatively low $\mathrm{OH} / \mathrm{C}$ ratio when compared to polysaccharides. So the water adsorption capacity in fibre wall is mainly determined by the amount and accessibility of hydroxyl groups.

The physical and chemical states of water in plant fibres depend on the surrounding environment. In ambient air, plant fibres are constantly exchanging moisture with atmosphere. Water molecules can be found in the form of bound water in the cell wall and water vapor within the fibre lumen. When fibres are exposed to liquid water (i.e. submerged in or in direct contact with liquid water), or when freshly cut, in addition to the bound water that is saturating the cell wall, liquid water can also fill the lumen by capillary suction. Water absorption in the cell wall is the result of a combination of complex mass transfer mechanisms as in all the open porous materials. It includes water vapor diffusion within the lumen and in the air surrounding the outer surface of the fibre, adsorption on the hydroxyl groups of hydrophilic polymers and diffusion of bound water in the wall.

When bast tissues or technical fibres are submerged in water, a separation of fibres is generally observed (see Fig. 1.4) due to the leaching and also to the degradation of the gummy substances (pectins mainly) surrounding the technical and individual fibres due to the action of enzymes produced by micro-organisms. This is the mechanism observed during water retting, one of the process employed to facilitate the separation of the fibres from the stem (Di Candilo et al. 2009).

Its versatility is also another important advantage, being useable in the form of fibres, felts, powders (byproducts, fragments, shives) and oils, due to the fact that the entire plant (seeds and plant stem) is recoverable. Indeed, all parts of the hemp plant can be used for myriad applications (Ranalli 1999; Bouloc 2013; Liberalato 2003; Ranalli and Venturi 2004; Amaducci et al. 2015). Figure 1.5 depicts a 
a)

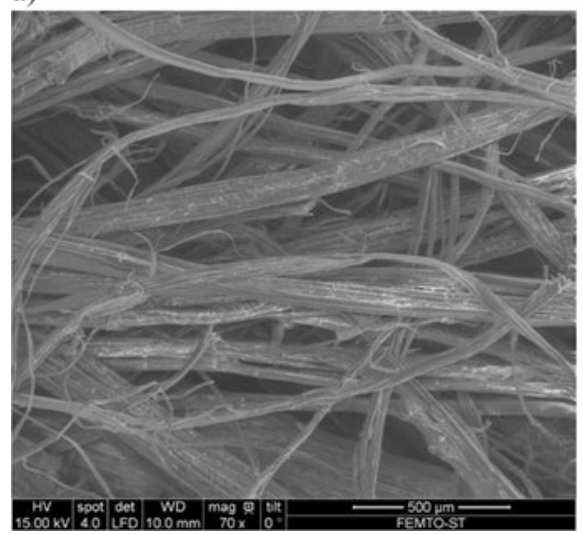

b)

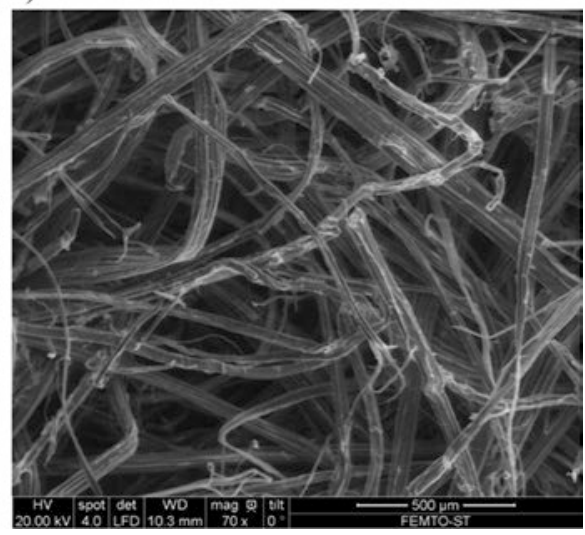

Fig. 1.4 Electron microscopy images of the fibre surface (a) before and (b) after washing by water

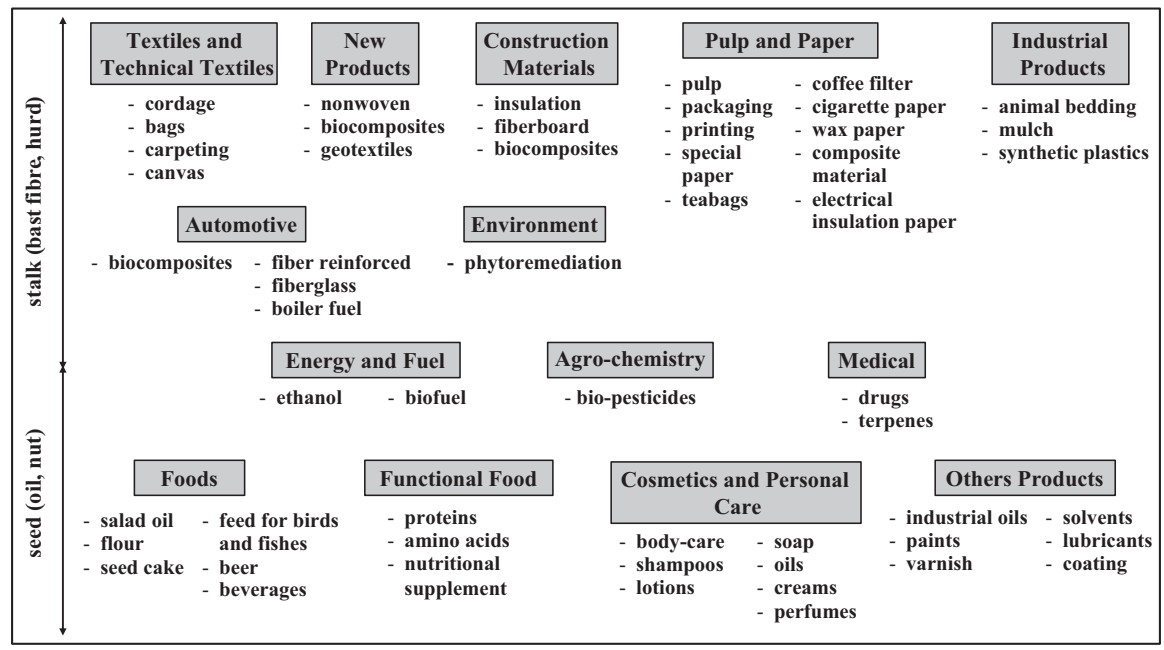

Fig. 1.5 Examples of multi-purpose hemp applications in domestic and industrial sectors

flowchart of multi-purpose hemp applications in domestic and industrial sectors. Hemp fibres and stalks are thus used for numerous applications such as in textiles (e.g. clothes, sport clothing, jeans, ropes, shoes, bags...) and pulp and paper industries (e.g. paper products, cardboard, packaging, filters), construction applications, biocomposites, agrochemistry, mulch and animal bedding. Textiles made from hemp are easy to produce, durable, versatile and biodegradable. Fibres are also more resistant to weather and ultraviolet rays than cotton and silk, and can be mixed with other materials to create clothing hybrids.

Oils are used for applications in cosmetics and body care products (e.g. soaps, shampoos, lotions, creams, perfumes...), pharmacy (e.g. to reduce acne breakouts and to improve skin conditions, interesting in dermatitis and eczema treatments), 
food-processing (e.g. health foods, nutraceutical products, protein isolates, beverages, animal food as feed for birds and fishes), agrochemistry, fuel (a by-product of its cultivation), paint, varnish, detergent, ink and lubricants. In cosmetology, hemp-based oils are interesting as additive due to their high concentration of fatty acids. In food chemistry, hemp is nutritious thanks to high levels of proteins, essential amino acids (rich in lanolin and linolenic acids), and other valuable elements (fibre, iron, potassium, zinc...). In China, hemp is widely used as a component for food and medicine.

Hemp can also be processed into different forms of felt, with various densities, used for example in automotive and construction applications (insulation materials) or as reinforcement in composite materials (plastic composites, biocomposites). Hemp provides all sorts of good building materials. They are durable, light weight, affordable to produce, and water-, fire- and rodent-proof. These materials are also ideal for resisting damage caused by earthquakes, floods or other natural disasters. Furthermore, the woody core part (shives) and short and entangled fibers obtained as by-product of hemp processing can be used in lower grade products such as insulation products, fiberboard and erosion control mats, while the fibrous core can be blended with lime to make strong, lightweight concrete (Ranalli and Venturi 2004; Shahzad 2012; Keijsers et al. 2013; Kostić et al. 2014).

Other innovative applications such as nanotechnology (e.g. nanomaterials with similar properties as graphene, supercapacitors and nanosheets), hemp plastic for 3D printing, biocomposites for airplanes, solar panels, bacteria-fighting fabric, bioactive metabolites such as cannabinoids, terpenoids and flavonoids, bio-pesticides, in cleaning up air and soil contamination, and biofuel production (with no sulfur emissions) opens new challenges (Citterio et al. 2003; Rehman et al. 2013). Indeed, one of the most interesting uses for hemp is in cleaning up soil contamination through phytoremediation process (Citterio et al. 2003). Hemp could be grown on soils contaminated with metals or radioactive elements. Hemp plants were shown to be effective in cleaning the soil around the site of Russia's Chernobyl nuclear disaster (Vandenhove and Van Hees 2003). Recently, they were considered for use near Fukushima. Hemp is also receiving more and more attention in water and wastewater treatment.

\subsection{A Novel Application of Hemp-Based Material for Removal of Metals: A Review of the Literature}

\subsubsection{Biosorption, a Useful Decontamination Process for Contaminant Removal}

Liquid/solid adsorption is one of the most frequently used techniques for the decontamination of aqueous media worldwide (Berefield et al. 1982; Volesky 1990; McKay 1996; Wase and Forster 1997; Cooney 1999; Crini and Badot 2010). 
Adsorption is a physical-chemical method of separation in which substances present in a liquid become bound to the surface of a solid material (Yang 2003; Volesky 2004). It is a process of partition of the molecule to be eliminated, called the adsorbate, between the aqueous solution and the solid, named the adsorbent or biosorbent/sorbent, depending on the type of material used.

The technique most frequently used to study adsorption (biosorption/sorption) phenomena, not only in research laboratories but also in the industrial sector, is the static approach or batch process. This approach involves mixing a known volume of water with known concentrations of adsorbate to be processed with a given quantity of adsorbent, in previously established conditions of stirring rate, stirring duration, concentration, $\mathrm{pH}$, ionic strength, and temperature. The mixture is stirred for a given contact time, then separated by a physical step involving centrifugation, sedimentation or filtration. By determining the concentrations in the supernatant and in the initial solution it is possible to calculate the efficiency of the solid material, i.e. its performance in terms of pollutant elimination (Crini and Badot 2010). This efficiency is generally compared to more conventional commercially available adsorbent systems, such as activated carbon, alumina or synthetic resins.

Batch methods are the most frequently used since they are simple, quick, and easy to set up (McKay 1996). In addition, they can be used to study the influence of a large number of parameters (e.g. pollutant concentration, $\mathrm{pH}$, ionic strength, temperature...) on the efficiency of the biosorbent, while easily obtaining reproducible results. For instance, by varying the contact time, the quantity of biosorbent or the concentration of the pollutant(s), it becomes possible to experimentally determine various isotherms and biosorption/adsorption kinetics and to model the process.

Modeling based on equations with 2 or more unknowns (see in particular the reviews of McKay and Al Duri (1989) and Ho et al. (2002) and the books of Berefield et al. (1982), Treybal (1987), Tien (1994), Volesky (1990, 2004) and McKay (1996)) provide information on adsorption mechanisms and enables interpretation depending on the conditions used in the batch. In industrial applications, batch techniques are used for example to "neutralize" abnormal peaks in the pollutant load at the entry to the water treatment plant, to recover economically interesting substances, such as noble metals, or to facilitate the production of denser sludge (Crini and Badot 2010; Sharma 2015).

Recently, the development of hemp-based materials as biosorbents is an expanding field in the area of pollutant removal. This is an interesting challenge because the majority of commercial polymers are derived from petroleum-based raw materials using processing chemistry that is not always safe or environmental friendly. Today, there is growing interest in developing natural low-cost alternatives to synthetic polymers. Hemp could be a promising alternative. Commercial hemp-based products are usually offered as powders (byproducts), fibres, or felts (Fig. 1.6).

To characterize hemp-based materials, numerous techniques such as Fourier transform infra-red spectrophotometry (FT-IR), energy-disperse X-ray spectroscopy (EDX), X-ray photoelectron spectroscopy (XPS), solid-state nuclear magnetic spectroscopy (NMR), differential scanning calorimetry (DSC), thermogravimetric analysis (TGA), contact angle measurement, and scanning electron microscopy 


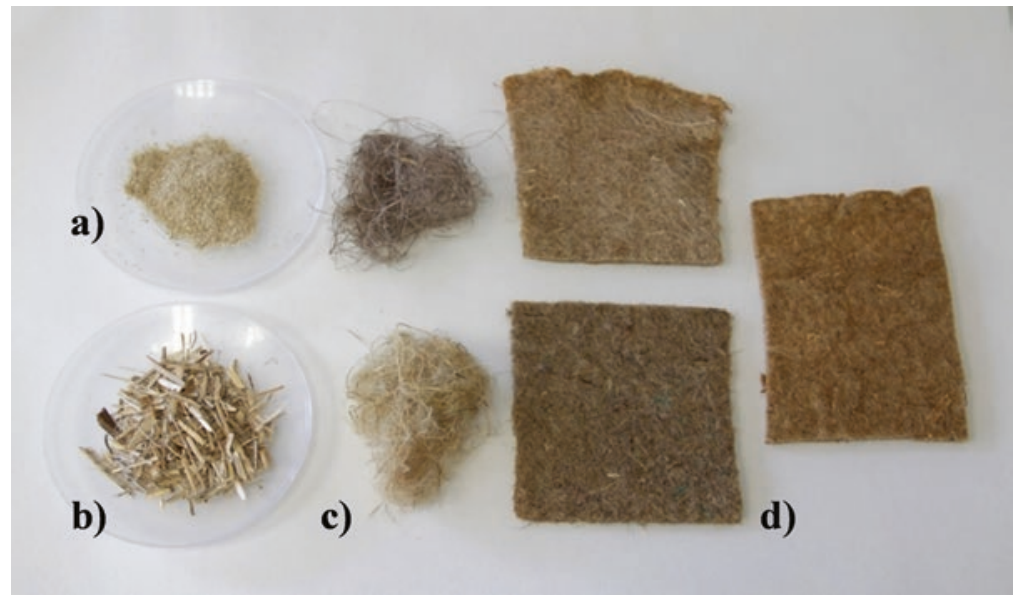

Fig. 1.6 Pictures of the hemp-based materials used as biosorbents: (a) sawdust, (b) hurds (shives), (c) fibres and (d) felt

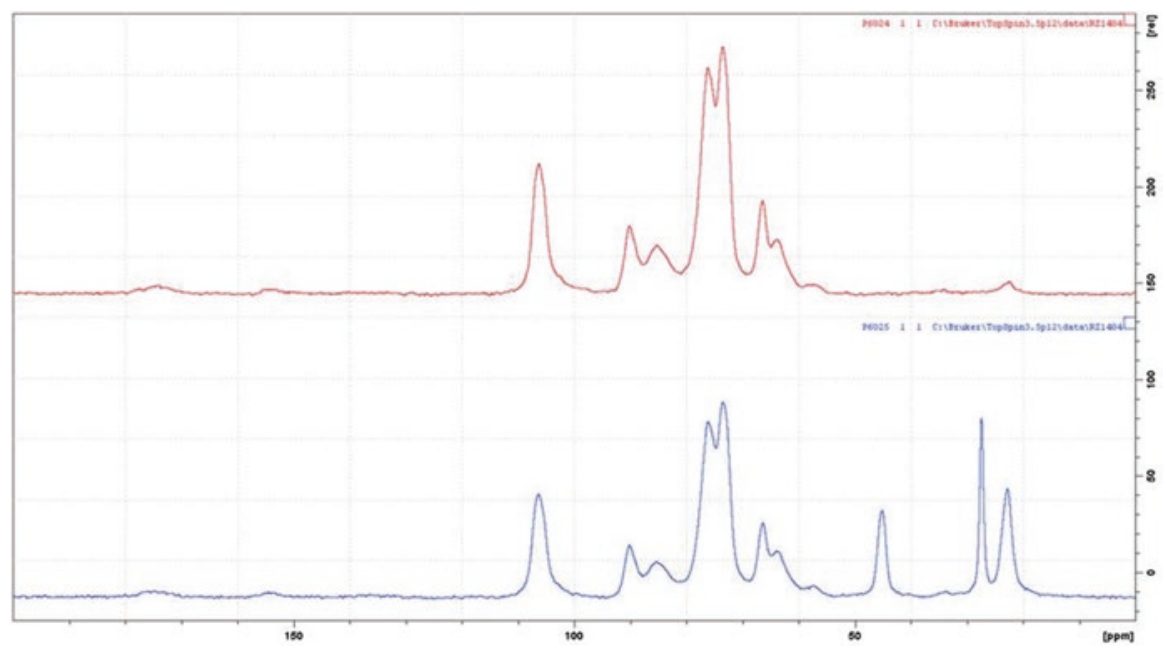

Fig. 1.7 Comparison of the ${ }^{13} \mathrm{C}$ NMR spectra of two felts containing hemp fibres without (in red) and with (in blue) the presence of an additive (10\% of polypropylene)

(SEM) can be used. For example, NMR is a powerful tool for hemp characterization. In Fig. 1.7, the solid-state ${ }^{13} \mathrm{C}-\mathrm{NMR}$ spectra show the peaks of disordered cellulose in the range 50 and $110 \mathrm{ppm}$. These broad signals are attributable to the glucopyranose unit of the cellulose structure of the raw fibres. The spectrum of felt containing $10 \%$ of polypropylene (PP, used as a matrix to reinforce fibres; typical applications on these composites include automotive interior substrates, furniture and other consumer products) clearly shows three additional peaks between 20 and $50 \mathrm{ppm}$ due to PP. 


\subsubsection{Hemp-Based Materials as Biosorbents}

Hemp-based biosorbents have been proposed for applications in water treatment, in particular for metal ion removal from aqueous synthetic solutions. Table 1.3 list some of the researchers whose results are discussed in this chapter and the pollutants they investigated.

The interaction between hemp and metal ions has been intensively investigated by Păduraru and co-workers using batch and fixed-bed column studies (Tofan and Păduraru 1999, 2000, 2004; Tofan et al. 2001a, b, 2009, 2010a, b, c, 2013, 2015, 2016a, b; Păduraru and Tofan 2002, 2008). These authors studied the capacity and mechanism of hemp fibres in removing different metals (i.e. $\mathrm{Cd}, \mathrm{Co}, \mathrm{Cr}, \mathrm{Cu}, \mathrm{Pb}, \mathrm{Ag}$ and $\mathrm{Zn}$ ) from aqueous monometallic solutions. Before use raw hemp fibres, wastes from the textile industry, were purified by boiling for $4 \mathrm{~h}$ in a solution containing soap and soda ash, followed by washing several times with water, and drying in an oven at $45^{\circ} \mathrm{C}$. Their investigations clearly indicated, for the first time, that hemp fibres had a high capacity for metals adsorption and were very useful for the treatment of wastewaters. Between 7.5 and $13.5 \mathrm{mg}$ of metal can be eliminated per gram of fibre, depending on the type of metal. For example, the monolayer adsorption capacity for $\mathrm{Cu}(\mathrm{II}) \mathrm{Cr}(\mathrm{III}), \mathrm{Cd}(\mathrm{II})$ and $\mathrm{Ag}(\mathrm{I})$ was 9.0735, 4.0006, 2.5909, and $1.2253 \mathrm{mg} / \mathrm{g}$, respectively. In all the experimental conditions tested, the order of affinity was the same: $\mathrm{Cu}>\mathrm{Cr}>\mathrm{Cd}>\mathrm{Ag}$ (Păduraru and Tofan 2002). The results also reported that hemp waste materials were efficient in removing $\mathrm{Co}$ (II), $\mathrm{Pb}$ (II) and $\mathrm{Zn}$ (II) from diluted and concentrated aqueous solutions.

In another work, the authors evaluated the thermodynamic feasibility of $\mathrm{Pb}$ (II) biosorption process on hemp by calculating thermodynamic parameters such as Gibbs free energy change $(\Delta \mathrm{G})$, enthalpy change $(\Delta \mathrm{H})$, and entropy change $(\Delta \mathrm{S})$. Evaluation of these parameters gives an insight into the possible mechanisms of adsorption. At all studied temperatures (between 277 and $333^{\circ} \mathrm{K}$ ), the $\Delta \mathrm{G}$ values were negative, showing the feasibility and spontaneous nature of $\mathrm{Pb}$ biosorption on fibres (Tofan et al. 2010b). $\Delta \mathrm{G}$ was estimated from the equilibrium adsorption data under the assumption that the adsorption of a pollutant was reversible and that an equilibrium condition was established in the batch system. The positive values of $\Delta \mathrm{H}$ indicated that $\mathrm{Pb}$ biosorption was an endothermic process, favored by temperature increase. The positive value of $\Delta S$ suggested an increased randomness at the interface of hemp-solution and high affinity of the hemp fibres for $\mathrm{Pb}$ ions. Kinetics were also rapid and could be described by a pseudo-first order model. The Langmuir model was found to be the most appropriate to describe the adsorption process in all the case of metals studied.

For Co removal, the authors showed that the biosorption capacity of the fibres used in column $(15.44 \mathrm{mg} / \mathrm{g})$ performed better than that of the batch system (13.58 mg/g) (Tofan et al. 2013). They explained this result by the fact that the gradient concentration decreased with time in batch experiments while it continuously increased in the interface of the biosorption zone in the column. The Langmuir model better described the Co(II) adsorption process on hemp fibres in comparison 


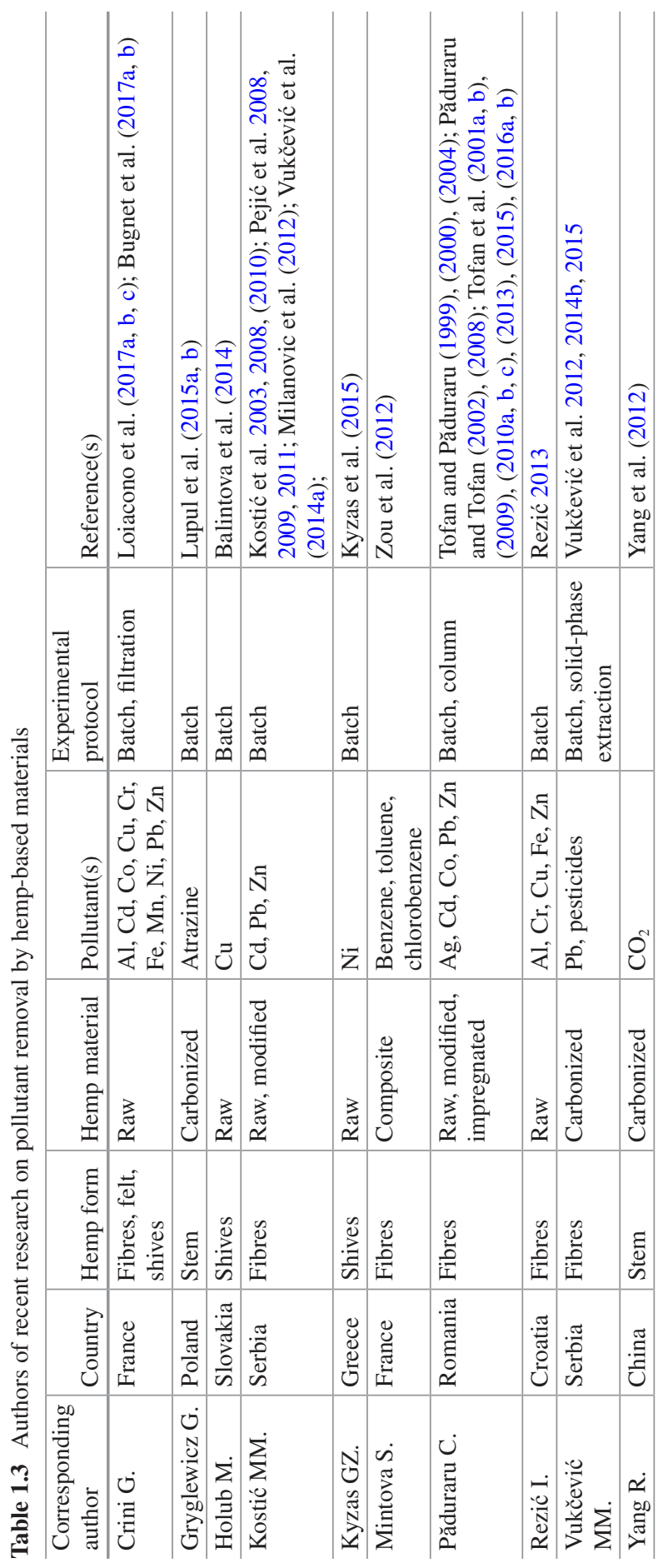


with the Freundlich model. This finding complied with the results of fixed-bed studies which emphasized that the optimal solution for describing the behavior of the investigated hemp bed column was provided by the Thomas model.

The authors explained their results by the fact that the main mechanism was chemisorption of the metal ion via the formation of electrostatic interactions, complexation and ion-exchange. Indeed, strong bonding of metal ions by carboxylic (present in hemicelluloses, pectin and lignin), phenolic (lignin and extractives), carbonyl (lignin) and hydroxyl (polysaccharides) groups were responsible of the adsorption through chemisorption.

Practical use of hemp has been mainly confined to the unmodified forms using spiked metal solutions. Although raw hemp fibres were useful for treating contaminated solutions, it may be advantageous to chemically modify hemp, e.g. by grafting reactions on cellulose macromolecules. Indeed, from the polymer chemist's point of view, the chemical substitution of cellulose offers enormous challenges. This chemical modification is interesting because, in polysaccharide chemistry, it is wellknown that the grafting of ligands can improve their adsorption properties (Crini 2005; George et al. 2015). Cellulose present an interesting reactivity due to the presence of numerous hydroxyl groups located on carbons 2,3 and 6 on each glucose residue of the cellulosic chains. In general, grafting of ligands resulted in fibres with reduce surface polarity and improved thermal and chelating properties. However, this chemical treatment can directly alter the surface and bulk chemical compositions of natural fibres. In addition, chemical treatment can also result in removal of significant amounts of components (cellulose, hemicellulose...), and therefore, it is important to characterize the modified fibres (Crini 2005; George et al. 2015).

In order to improve the performance of raw hemp fibres, Păduraru's group proposed a chemical treatment using $\beta$-mercaptopropionic acid as chelating agent. This functionalization permitted to introduce sulphydryl functional groups onto surface fibres (Tofan and Păduraru 2004). A systematic study on the $\mathrm{Ag}$ (I), Cd(II) and $\mathrm{Pb}$ (II) removal onto these raw and modified fibres was realized under similar experimental batch conditions. For raw and modified hemp, the adsorption capacities were 1.2253 and $10.75 \mathrm{mg} / \mathrm{g}$ for $\mathrm{Ag}(\mathrm{I})$ and 2.5909 and 14.05 for Cd(II), respectively. This clearly demonstrated the important role of sulphydryl chelating groups. However, for $\mathrm{Pb}$ (II), the adsorption capacity decreased, but no explanation was given.

Tofan et al. (2015) studied Cr(III) removal from aqueous solutions by adsorption in a fixed bed column filled with alizarin $\mathrm{S}$ impregnated hemp fibres. The breakthrough time and saturation time decreased from 110 to $80 \mathrm{~min}$ and from 300 to $160 \mathrm{~min}$, respectively, with the increase in the initial concentration from $13.00 \mathrm{mg} / \mathrm{L}$ to $26.14 \mathrm{mg} / \mathrm{L}$. The increase in the initial concentration from 13.00 to $26.14 \mathrm{mg} / \mathrm{L}$ increased the breakthrough adsorption capacity from 4.178 to $6.163 \mathrm{mg} / \mathrm{g}$ and decreased the percentage of $\mathrm{Cr}$ (III) removal from $73.57 \%$ to $62.64 \%$. The breakthrough predictions by Thomas model were found to be very satisfactory. The hemp impregnated with alizarin S column removed $>90 \%$ of $\mathrm{Cr}$ (III) from three samples of synthetic wastewaters containing different amounts of other heavy metal ions. All these findings were significant for the future development of hemp materials for metal removal from industrial effluents. 
Polysaccharide-based biosorbents present considerable advantage including their high adsorption capacity and selectivity but also the facility of regeneration. The regeneration of saturated hemp biosorbent for non-covalent adsorption can be easily achieved by using an acid solution as the desorbing agent. In a recent work, batch studies on desorption and multiple adsorption-regeneration cycles for $\mathrm{Zn}$ removal by natural hemp fibres have been carried out by Tofan et al. (2016a). The best desorption results were performed in acidic medium, where the protons in solution replaced the $\mathrm{Zn}$ ions on the loaded hemp. The efficiency of $\mathrm{Zn}$ desorption with $0.1 \mathrm{M}$ hydrochloric acid was higher than that achieved using sulfuric acid of the same concentration. The amount of $\mathrm{Zn}$ desorbed by $0.1 \mathrm{M} \mathrm{HCl}, 0.1 \mathrm{M} \mathrm{H}_{2} \mathrm{SO}_{4}$, and $5 \% \mathrm{NaCl}$ increased sharply in the first $15-20 \mathrm{~min}$ of the process, attaining values that subsequently stay almost constant (for $0.1 \mathrm{M} \mathrm{HCl}$ ) or slightly increase (for $0.1 \mathrm{M} \mathrm{H}_{2} \mathrm{SO}_{4}$ and $5 \% \mathrm{NaCl}$ ). The adsorptive potential of the tested hemp remained almost unchanged after three cycles of adsorption-desorption of $\mathrm{Zn}$ from solutions. This showed both the chemical stability of the biosorbents and reproducibility of the values. The results of this study were also important in order to demonstrate that regenerated hemp could be used for $\mathrm{Zn}$ metal removal from water sources without the threat of the adsorbent becoming another source of $\mathrm{Zn}$ pollution for the environment. From their numerous results, Păduraru's research group concluded that hemp and its derivatives may be a useful and promising biosorbent in water and wastewater treatment.

Kostić's group also published a series of papers on the ability of hemp to act as an effective biosorbent for the removal of metals from aqueous solutions (Pejić et al. 2009, 2011; Kostić et al. 2010, 2014; Vukčević et al. 2014a). Their results clearly demonstrated that hemp in fibre form had a high affinity for $\mathrm{Cd}, \mathrm{Zn}$ and $\mathrm{Pb}$, in accordance with the results published by Păduraru's group. In order to obtain better adsorption capacities, these authors also proposed to modify fibres by simple and inexpensive alkaline and oxidative treatments, causing gradual removal of either hemicelluloses or lignin and altering fibre structure. Observed increase in adsorption properties was ascribed not only to the decrease of lignin or hemicelluloses content, but also to the increased fibre fibrillation, surface peeling and roughness increase, which affects fibre specific surface area. Besides changes in fibre surface and structure, applied chemical treatments affects the amount and accessibility of functional groups incorporated in the fibre structure. Both chemical treatments used remove the accompanying components from the fibre surfaces, leading to the liberation of the functional groups, and increasing their amount. Since functional groups act as active sites for adsorption, chemical modification efficiently improve the adsorption properties of this biosorbent.

Similar materials and results were published by Kyzas's group for the removal of $\mathrm{Ni}$ from diluted and concentrated solutions (Kyzas et al. 2015). They noted that adsorption capacities between 160 and $206 \mathrm{mg}$ of Ni per gram of material were achieved. The differences in the degree of performance were mainly attributed to the hemp form used (fibres or shives). After chemical modification (by sodium hydroxide or citric acid), the respective capacities were improved to 237 and $242 \mathrm{mg} / \mathrm{g}$, respectively. A characterization study (FT-IR, XRD, SEM, EDX, crystal- 
linity, and cellulose content) demonstrated the surface morphology of the modified hemp along with some possible biosorption interactions between them and Ni. At least ten sequential reuse cycles revealed the reuse potential of the modified hempbased materials. The authors concluded that hemp fibres were a promising material for the removal of $\mathrm{Ni}$ from single ion solution mainly through chemical interactions.

Balintova et al. (2014) studied the removal of $\mathrm{Cu}$ onto raw hemp shives and treated hemp by $\mathrm{NaOH}$. This treatment permitted to remove either hemicelluloses or lignin. However, no significant differences were obtained. The adsorption capacities for raw and treated hemp were 3.91 and $4.45 \mathrm{mg} / \mathrm{g}$, respectively (conditions: dosage $=1 \mathrm{~g} / 100 \mathrm{~mL}$; initial $\mathrm{Cu}$ concentration $=50 \mathrm{mg} / \mathrm{L}$, initial $\mathrm{pH}=4$, and contact time $=24 \mathrm{~h}$ ). These performances were compared with those of commercial sorbents and similar adsorption capacities were obtained. The authors concluded that hemp was a useful non-conventional biosorbent for copper removal from acidic environment.

New hemp fibres derivatives in environmental, pharmaceutical and biomedical fields to reduce metal pollution and to prevent bacteria growth were proposed by Cassano et al. (2013). The materials were prepared via esterification of hemp with 2-benzyl-4-chlorophenol (a germicide agent), that was covalently coupled to cellulose backbone of fibres by a heterogeneous process. Carboxylated materials were also synthetized. FT-IR spectroscopy was used to obtain qualitative information on hemp fibres after derivatization. The materials were also characterized using differential scanning calorimetry. The new materials possessed an excellent in vitro antibacterial activity in inhibiting Staphylococcus aureus and Pseudomonas aeruginosa growth and also exhibited interesting adsorption capacities toward $\mathrm{Cd}$ present in aqueous solutions. However, the performances for $\mathrm{Cd}$ removal were dependent on $\mathrm{pH}$ solution. In addition, their results showed that carboxylated fibres had a higher chelating capacity than the esters derivatives.

All these studies demonstrated that hemp could be a viable biosorbent for environmental applications. However, these previously published works focused on the removal of only one or two metals at a time using hemp in fibre form. Recently, Crini's group proposed the use of a hemp-based material in felt form to treat polymetallic aqueous solutions, containing a mixture of six metals, namely $\mathrm{Cd}, \mathrm{Co}, \mathrm{Cu}$, Mn, Ni and Zn (Bugnet et al. 2017a, b; Loiacono et al. 2017a, b, c). These six metals were studied due to their common presence in discharge waters from the metal industry. Adsorption experiments showed that this non-conventional biosorbent exhibited interesting adsorption capacities. In $10 \mathrm{~min}, 1 \mathrm{~g}$ of material was able to remove $7.4 \mathrm{mg}$ of metals $($ total $=2.14(\mathrm{Cu})+1.69(\mathrm{Cd})+1.3(\mathrm{Zn})+0.93(\mathrm{Ni})+0.84$ $(\mathrm{Co})+0.5(\mathrm{Mn}))$ at a concentration of $25 \mathrm{mg} / \mathrm{L}$ for each metal present in $100 \mathrm{~mL}$ of solution. The results were also almost independent of $\mathrm{pH}$ between 4 and 6 . The following order was obtained: $\mathrm{Cu}>>\mathrm{Cd}>\mathrm{Zn}>\mathrm{Ni} \sim \mathrm{Co}>\mathrm{Mn}$, while, in single solution, the order was $\mathrm{Cd}>\mathrm{Cu}>\mathrm{Zn}>\mathrm{Co} \sim \mathrm{Ni}>\mathrm{Mn}$. Figure 1.8 shows material before and after batch, indicating the coloring of the felt after metal removal. This was the 


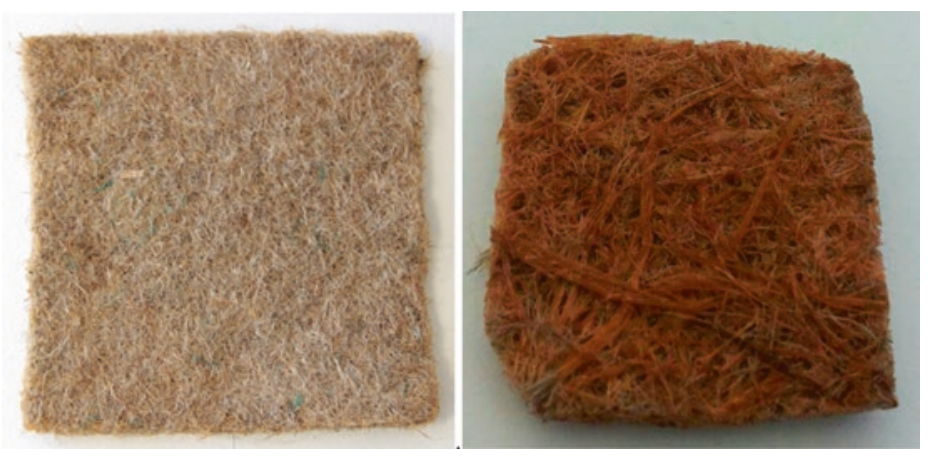

Fig. 1.8 Hemp felt before (left) and after adsorption (right) in a solution containing a mixture of six metals

first report on the removal of metals from polycontaminated aqueous solutions by hemp-based material in felt form (Loiacono et al. 2017a).

In another work, in order to ameliorate its adsorption properties towards the same six cationic metal species, the authors proposed to modify chemically the raw felt (Loiacono et al. 2017b). The felt was treated with a mixture of maltodextrin (MALTO), an oligosaccharide obtained from starch hydrolysis, and 1,2,3,4 butanetetracarboxylic acid (BTCA) used as cross-linking agent. This chemical treatment provided ion-exchange properties to the material by introducing carboxylic groups on hemp fibres. Potentiometric titration data revealed that the quantity of carboxylic groups was increased from $0 \pm 0.09 \mathrm{meq} / \mathrm{g}$ for raw hemp to $0.67 \pm 0.03 \mathrm{meq} / \mathrm{g}$ for modified hemp. A weight increase of $35 \%$ of modified felt confirmed that a crosslinking reaction occurred by esterification between BTCA carboxylic groups and MALTO hydroxyl groups on the one hand, and cellulose hydroxyl group of hemp fibres on the other hand. The modified material was also characterized using solid state NMR technique, SEM and EDX. For the total metal load, the adsorption capacity of modified hemp was determined to be twofold higher than that of nonmodified felt in all conditions studied. The carboxylic groups present in BTCA were responsible for metal ion binding through chemisorption mechanism (e.g. complexation, electrostatic interactions, ion-exchange) and their presence in modified material positively influenced its performance. Nevertheless, in the multi-component system studied, strong competition prevails among metallic species for the binding sites. For modified hemp, the following order was obtained: $\mathrm{Cu}>\mathrm{Cd}>\mathrm{Zn}>\mathrm{Mn}>\mathrm{Ni}$ $\sim \mathrm{Co}$, while, in single solution, the order was $\mathrm{Cd}>\mathrm{Cu} \sim \mathrm{Zn} \sim \mathrm{Mn}>\mathrm{Ni} \sim \mathrm{Co}$. Interesting results were also obtained for real effluents containing the same six metals (Loiacono et al. 2017a). Crini's group concluded that raw and modified hempbased materials in felt form can be utilized as an interesting tool for the purification of metal-containing wastewater because of their outstanding adsorption capacities and easy of use. 


\subsubsection{Composite Materials}

Zou et al. (2012) proposed a hemp-zeolite composite material obtained by a simple procedure for the removal of aqueous aromatic organic pollutants (benzene, toluene and chlorobenzene). This new biosorbent, prepared via in situ crystallization of zeolite L nanocrystals on hemp fibres, exhibited a high removal degree (above 80\%). The order obtained was: chlorobenzene $>$ benzene $>$ toluene. The composite also presented high flux of $19.9,19.3$ and $20.9 \mathrm{~kg} / \mathrm{m}^{2} \mathrm{~h}$ for chlorobenzene, benzene and toluene, respectively. The results showed that the removal of the composite was much higher in respect to only hemp fibres (48\%). The better performance of the composite was explained by an improved absorption ability of the zeolite-hemp material coupled with higher dynamic separation efficiency. In addition, this new material possessed high mechanical and chemical stabilities before and after water purification, demonstrated by XRD and SEM experiments. The authors concluded that, both materials (zeolite L and hemp) used for preparation of the composite were environmentally friendly, and made the adsorbents particularly appropriate for water purification.

\subsubsection{Activated Carbons from Hemp}

Amongst all the commercial adsorbents materials proposed, activated carbon (AC) is the most popular adsorbent for the removal of pollutants from the wastewater (Ramakrishna and Viraraghavan 1997; Derbyshire et al. 2001; Babel and Kurniawan 2003). The world demand of AC is steadily increasing due to its high performance in many purification and separation processes. The most commonly used raw precursors are wood, coal, coconut shells and some commercial polymers. However, the use of carbons based on relatively expensive starting materials is unjustified for most pollution control applications (Streat et al. 1995). This had led many researchers to search for more economic carbon-based adsorbents from non-conventional resources. Indeed, certain waste products from various industrial by-products (wastes generated during lactic acid fermentation from garbage, waste carbon slurries...), city wastes (PET bottles, waste tires, waste newspaper...), and agricultural operations (bagasse, date pits, corn cob...), including lignocellulosic and wood byproducts (pinewood, sawdust, lignin, sugarcane...), represent potentially economical alternative material to prepare activated carbon. These waste materials have little or no economic value and often present a disposal problem. Therefore, there is a need to valorize these low-cost by-products. So, their conversion into activated carbon would add its economic value, help reduce the cost of waste disposal, and most importantly provide a potentially inexpensive alternative to the existing commercial activated carbons as reported by Oliveira and Franca (2008). 


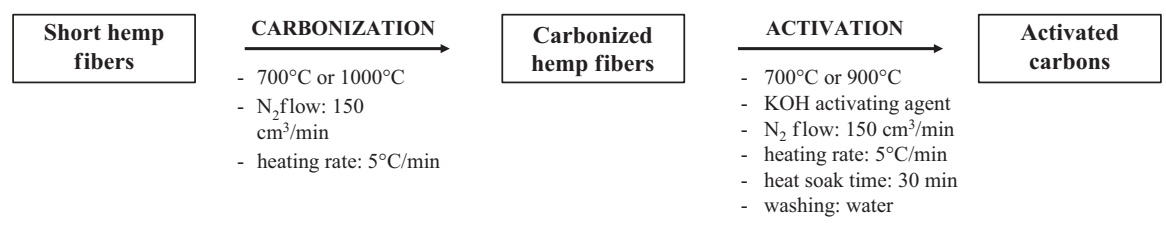

Fig. 1.9 Scheme of activated carbons production from hemp-based wastes. (Adapted from Vukčević et al. 2015)

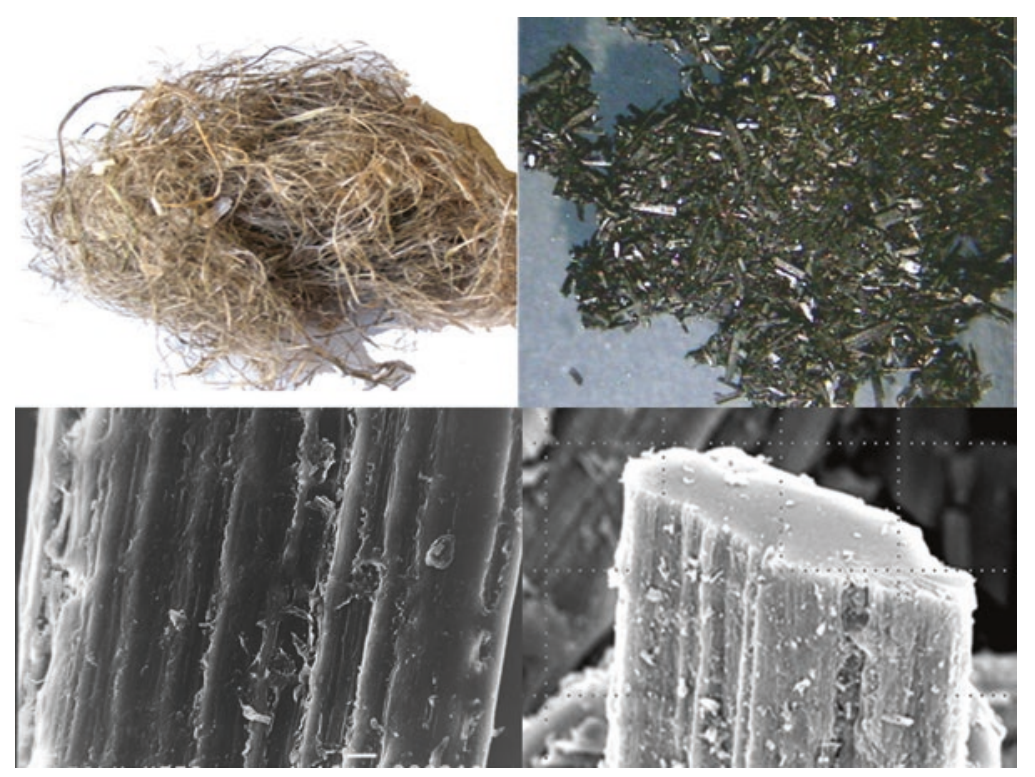

Fig. 1.10 Short hemp fibers before (left) and after (right) carbonization. (Adapted from Vukčević et al. 2015)

Although hemp has many practical applications, its transformation generates a high proportion of waste. Development of recycling processes of such biomass waste is generating great interest, and the production of activated carbon could be an appropriate solution. There are several reports on the production of activated carbon from hemp-based materials (Rosas et al. 2009; Vukčević et al. 2012, 2014b, 2015; Yang et al. 2011, 2012; Sun et al. 2013; Wang et al. 2015; Lupul et al. 2015a, b).

An important work on this topic was done by Vukčević and co-workers (Vukčević et al. 2012, 2014b, 2015). They proposed activated carbon from waste short hemp fibres as adsorbent for metal ions and pesticides removal. Activated carbon with high specific surface area (up to $2192 \mathrm{~m}^{2} / \mathrm{g}$ ) and microporous structure were prepared by carbonization of waste hemp fibres and activation with KOH. Figure 1.9 depicts the synthesis procedure used while Fig. 1.10 shows hemp fibers before and after carbonization. These non-conventional carbons exhibited high adsorption properties toward metals such as $\mathrm{Pb}$ and 15 pesticides including atrazine, simazine, 
malathion and linuron. Their results showed that the adsorption capacities of an activated carbon depend on the history of its preparation and treatment conditions such as pyrolysis temperature and activation time. The best efficiency was achieved with samples with the highest specific surface area and the amount of surface oxygen groups. Many other factors can also affect the adsorption capacity in the same adsorption conditions such as surface chemistry (heteroatom content), surface charge and pore structure (Vukčević et al. 2015). In general, specific surface area and pore size distribution are dominant factors of influence in the case of physical adsorption of nonpolar organic molecules, while adsorption of inorganic and polar organic compounds is also influenced by surface chemistry of carbon adsorbent.

The specific adsorption mechanisms by which the adsorption of pollutant takes place on these non-conventional carbons are still not clear. This is because of the fact that adsorption onto carbon adsorbent is usually complex process that may occur through the mechanism of physisorption (e.g. hydrophobic interactions, electrostatic attraction...), and chemisorption (e.g. surface complexation ion-exchange...). For example, metal ions adsorption on carbon surface can be considered as physisorption if it occurs through the mechanism of electrostatic attraction between metal ions and graphene layer's $\pi$ electrons. Furthermore, oxygen groups present on the carbon surface might behave as ion-exchange sites for the retention of metal ions. From the other hand, surface functional groups can also act as active chemisorption sites, since oxygen in the surface functional groups possesses a pair of lone electrons (Lewis base) and therefore may coordinate with electron deficient metal ions (Lewis acid). In the case of organic molecules, the surface chemistry of the carbon has a great influence on adsorption, both in the case of electrostatic and non-electrostatic interactions. Electrostatic interactions, which can be either attractive or repulsive, strongly depend on the charge densities of both the carbon surface and the adsorbate molecule, as well as of the ionic strength of the solution. The non-electrostatic interactions, which are always attractive, include van der Waals forces, hydrophobic interactions and hydrogen bonding. Aromatic compounds can be physisorbed on carbon materials essentially by dispersion interactions between the $\pi$ electrons of the aromatic ring and those of the graphene layers. The presence of aromatic rings, as well as a branched substituent on the aromatic ring, increased the level of organic compound adsorption. On the other hand, electron-acceptor surface groups, present on the carbon adsorbent surface, can withdraw $\pi$ electrons from the graphene layers, decreasing the dispersive interactions and leading to reduced adsorption. On the base of obtained results, Vukčević and co-workers concluded that application of hemp wastes as new solid-phase extraction adsorbent was a procedure of choice for analysis of pesticides in water samples with recoveries comparable or even better than those obtained with commercial cartridges.

Similar interesting results were published by Lupul et al. (2015a, b). These authors proposed adsorption of atrazine on hemp stem-based activated carbon with different surface chemistry using potassium hydroxide as activating agent. The presence of oxygen and nitrogen functionalities on the carbon surface was found to be undesirable for atrazine adsorption. The superior adsorbent was obtained by heat treatment of activated carbon in an inert atmosphere at $700{ }^{\circ} \mathrm{C}$, resulting in a very 
high adsorption capacity due to its enhanced hydrophobicity. Adsorption capacities were in the range 169-227 mg/g depending on the chemical treatment (Lupul et al. $2015 \mathrm{a}$ ). The adsorption of atrazine on the studied carbons mainly involves $\pi-\pi$ dispersive interactions between the atrazine $\pi$ electron ring and the $\pi$ electron of graphene layers of carbon. The Langmuir-Freundlich and Langmuir models gave a better fit for equilibrium isotherms compared with the Freundlich model. Modeling also showed that the atrazine adsorption process was controlled by an intraparticle diffusion mechanism into small micropores with a significant contribution from film diffusion.

Rosas et al. (2009) proposed hemp-based activated carbon fibres by chemical activation with phosphoric acid at different carbonization temperatures and impregnation rates. Surface properties of the fibres were significantly influenced by the activation temperature and the impregnation ratio. An increase of either of these parameters produced a high development of the porous structure of the fibres. Activated carbon fibres with apparent surface area of $1350 \mathrm{~m}^{2} / \mathrm{g}$ and mesopore volume of $1.25 \mathrm{~cm}^{3} / \mathrm{g}$ were obtained at $550{ }^{\circ} \mathrm{C}$ with an impregnation ratio of 3 . The fibres presented a high oxidation resistance due to the presence of phosphorus compounds on the carbon surface. The oxidation resistance results suggested that C-O- $\mathrm{PO}_{3}$ and mainly C-PO $\mathrm{P}_{3}$ and C-P groups act as a physical barrier, blocking the active carbon sites for the oxidation reaction. The authors concluded that the use of hemp residues to produce activated carbon was very feasible and presented the advantage of the potential revalorization of a residual material. Williams and Reed $(2003,2004)$, studying the preparation of activated carbon fibres by physical activation with steam and chemical activation with $\mathrm{ZnCl}_{2}$ of hemp fibres, previously published a similar conclusion.

Yang and co-workers (Yang et al. 2011, 2012; Wang et al. 2015) also prepared activated carbon fibres using hemp bast and a simple method consisting in a phosphoric acid activation at different temperatures. These carbons were then used as sorbents for dye removal. The textural properties of the activated carbon fibres were found to be strongly dependent on the activation temperature. Activated carbon fibres exhibited narrow pore size distributions with maxima in the micropore and small mesopore regions. BET surface area, total pore volume, micropore volume and mesopore volume increased with the increase of activation temperature up to $450{ }^{\circ} \mathrm{C}$ and then decreased with further heating, and a sample with maximum surface area of $1142 \mathrm{~m}^{2} / \mathrm{g}$ and total pore volume of $0.67 \mathrm{~cm}^{3} / \mathrm{g}$ was obtained. Phosphoric acid facilitated the conservation of porous structure in the precursor fibres, led to the creation of tremendous porosity, and resulted in various phosphore-containing functional structures on the surface and in the bulk phase of the resultant samples. The adsorption of Acid Blue 9 as guest compound on the sample could be favorably described by Langmuir isotherm $\left(\mathrm{q}_{\max }=28.75 \mathrm{mg} / \mathrm{g}\right)$, and the adsorption kinetics was found to be well fitted by the intraparticle diffusion model. Yang et al. (2011) concluded that hemp bast was a suitable low-cost byproduct for use in the production of activated carbon for dye removal, thus contributing for the implementation of sustainable development in both the hemp production and environmental protection. 
In another recent work, the same authors presented a new route for high-valueadded utilization of hemicellulose extracted from hemp stem to prepare well-shaped carbon spheres (Wang et al. 2015). Activated carbon with high large surface area up to $2192 \mathrm{~m}^{2} / \mathrm{g}$ were prepared by an improved low-temperature hydrothermal carbonization method and $\mathrm{KOH}$ activation. A pre-carbonization strategy before activation was also employed to keep activated carbon in perfectly spherical morphology even at a high $\mathrm{KOH} /$ carbon ratio 5/1. The characterization of activated carbon demonstrated that the surface area, micropore volume, mesopore volume and surface oxygen content all increases with increasing $\mathrm{KOH} /$ carbon ratio. Activated carbon exhibited excellent electrochemical performance due to abundant micropores and plentiful oxygen functionalities, and showed good adsorption capacities of $\mathrm{CO}_{2}$ and $\mathrm{CH}_{4}$ at ambient pressure and $0{ }^{\circ} \mathrm{C}$. The authors concluded that activated carbon converted from inexpensive hemp stem could be potential materials for $\mathrm{CO}_{2}$ and $\mathrm{CH}_{4}$ storage (Wang et al. 2015).

Sun et al. (2013) prepared mesoporous activated carbon using hemp stem as precursors by air-phosphoric acid activation method. The crystallite size of carbon was small, and its pores was larger. The phosphoric acid solution concentration had a signification effect on pore structure and adsorption property of activated carbon. The mesopore activated carbon attained at phosphoric acid solution concentration of $50 \%$ exhibited a maximum BET specific surface area of $1351 \mathrm{~m}^{2} / \mathrm{g}$, total pore volume of $1.21 \mathrm{~cm}^{3} / \mathrm{g}$, mesopore pore volume of $0.90 \mathrm{~cm}^{3} / \mathrm{g}$ and a mesopore fraction of $74.4 \%$. The resulting carbon had smaller crystal size, developed pore structure, wider pore size distribution.

\subsection{Conclusion}

The past decade has seen an intense interest in hemp-based biosorbents for metal ion removal from aqueous synthetic solutions. Many biosorbents in raw, modified or carbon forms could be used for this purpose. Outstanding removal capacities for metals were reported. Table 1.4 presents a summary of some of the highest adsorption capacities reported (the $\mathrm{q}_{\max }$ values are expressed in $\mathrm{mg}$ of pollutant per $\mathrm{g}$ of biosorbent). Which material is better? There is no direct answer to this question because the biosorption capacity depends on the residual concentration of the pollutant in the solution. The uptake by two materials must be then compared only at the same equilibrium concentration. In addition, the comparison of performance also depends on several other parameters related to the solution and analytical method used. Thus, a direct comparison of data obtained using different materials is not possible since experimental conditions are not systematically the same. However, the authors believe that hemp can compete with conventional adsorbents for wastewater treatment. Although interesting works at the stage of laboratory-scale study has been done, future research needs to look into some of the following: (i) it is necessary to continue to search for and select the most promising types of 


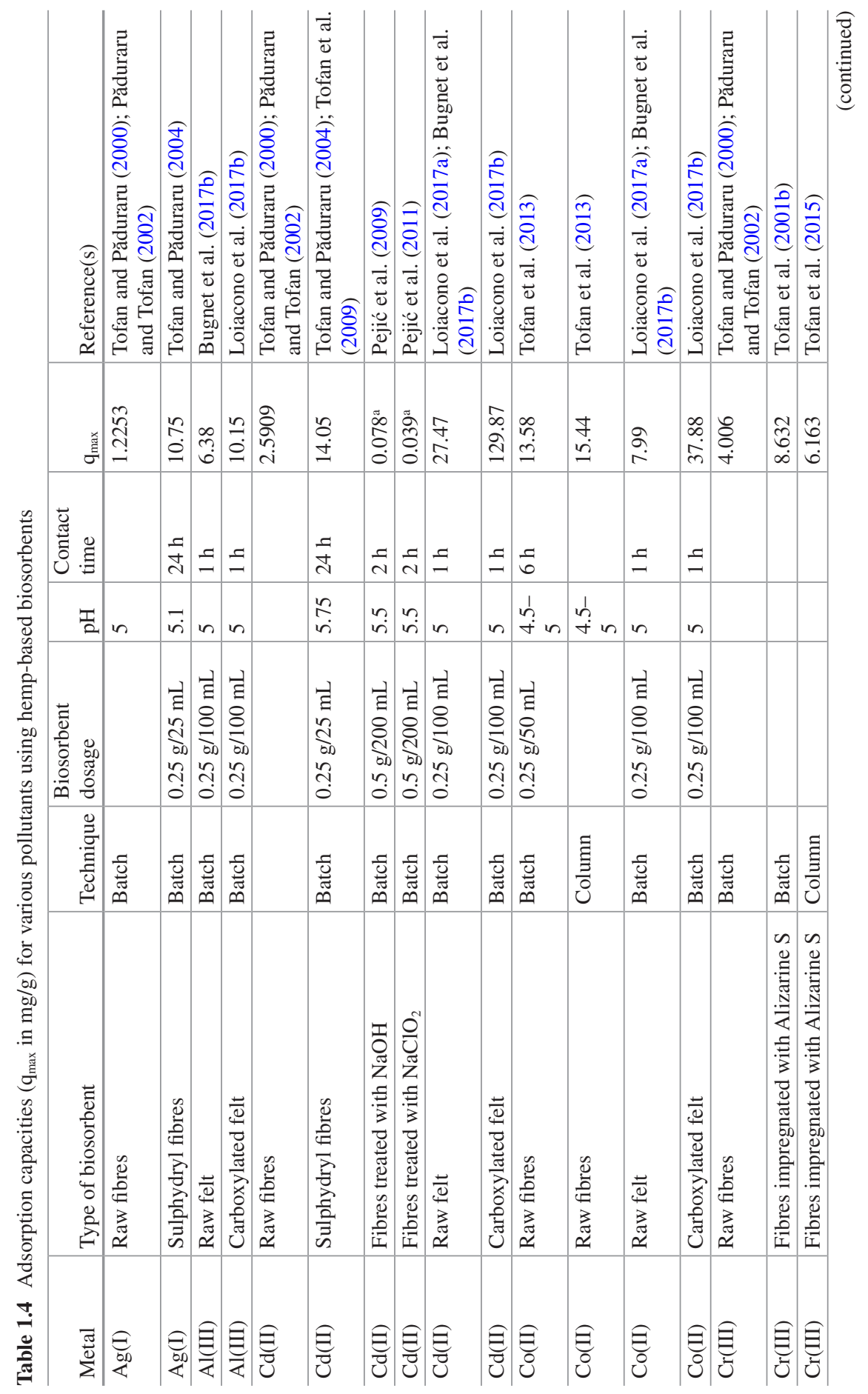




\begin{tabular}{|c|c|c|c|c|c|c|c|c|c|c|c|c|c|c|c|c|}
\hline 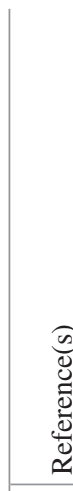 & 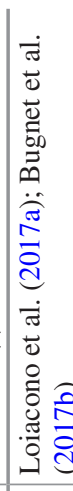 & 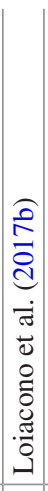 & 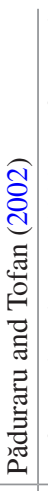 & 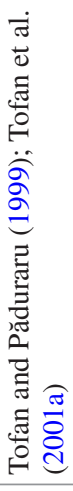 & 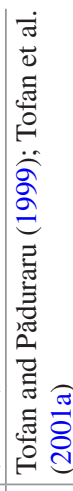 & 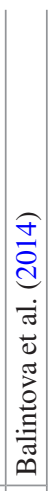 & 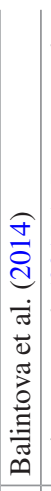 & 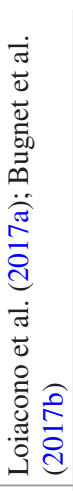 & 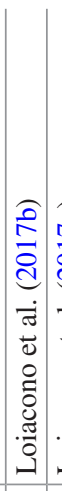 & 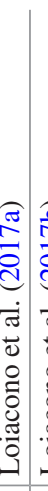 & 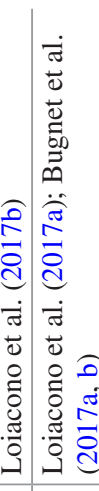 & 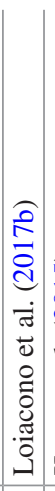 & & 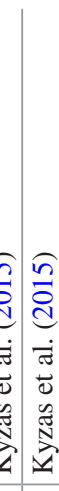 & 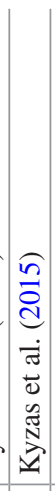 & 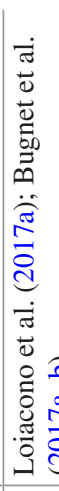 \\
\hline & {$\left[\begin{array}{l}n \\
b\end{array}\right.$} & 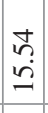 & $\begin{array}{l}n \\
\tilde{n} \\
\vdots \\
\vdots \\
\vdots\end{array}$ & $\begin{array}{l}\infty \\
\stackrel{\infty}{\delta} \\
\substack{\infty \\
\infty}\end{array}$ & 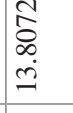 & $\overline{\dot{m}}$ & 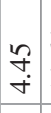 & $\begin{array}{l}\text { d̦ } \\
\stackrel{+}{ \pm}\end{array}$ & & 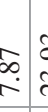 & \begin{tabular}{c|c}
$\hat{\sigma}$ & $n$ \\
& $n$ \\
+
\end{tabular} & $\begin{array}{l}\stackrel{\sim}{2} \\
\dot{f}\end{array}$ & בูป & $\hat{~}$ & $\stackrel{8}{6}$ & $\begin{array}{l}n \\
\infty \\
\infty \\
i\end{array}$ \\
\hline 。 & $\Xi$ & $\Xi$ & & & & $\underset{d}{\stackrel{s}{d}}$ & 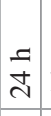 & $=$ & $\Xi$ & $\Xi$ & $\Xi \pm$ & & $\frac{5}{d}$ & 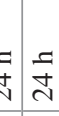 & $\frac{5}{\grave{d}}$ & $=$ \\
\hline I & in & in & & & & ナ & 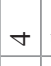 & in & in & in & $n$ & in & in & in & in & in \\
\hline 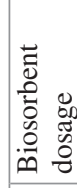 & 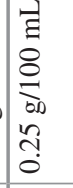 & 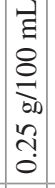 & & & & $\frac{\vec{g}}{8}$ & 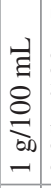 & 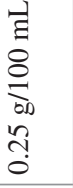 & 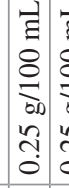 & 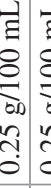 & 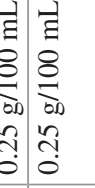 & 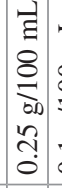 & 0 & 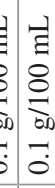 & 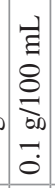 & 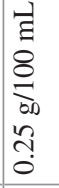 \\
\hline 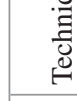 & $\begin{array}{l}\overline{\tilde{u}} \\
\bar{u} \\
\tilde{n}\end{array}$ & 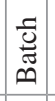 & 竧 & 矛 & $\begin{array}{l}\overline{\tilde{y}} \\
\tilde{y} \\
\tilde{n}\end{array}$ & 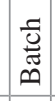 & 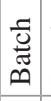 & 离 & & 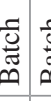 & 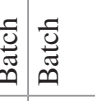 & & 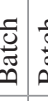 & 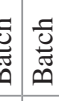 & 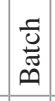 & 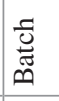 \\
\hline 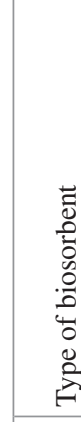 & 苞 & 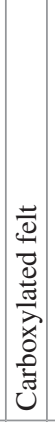 & 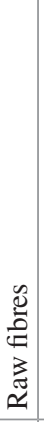 & 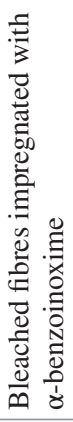 & 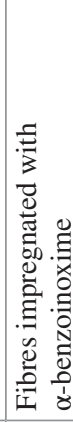 & $\sum_{\substack{n \\
\omega}}^{0}$ & 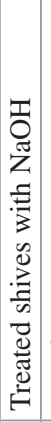 & 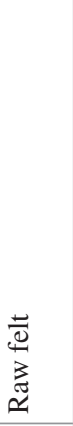 & 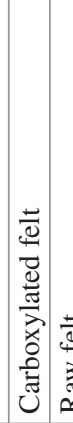 & 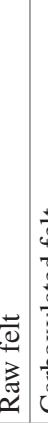 & 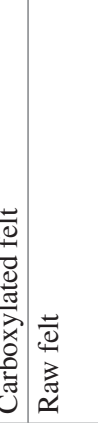 & 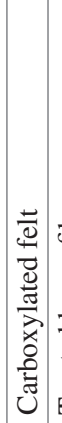 & 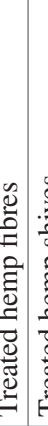 & 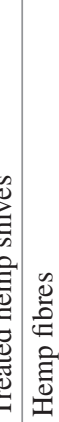 & 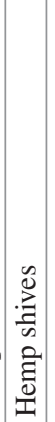 & 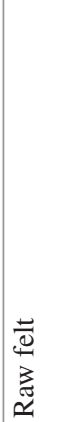 \\
\hline$\frac{\sqrt{\pi}}{2 \pi}$ & U & U઼ & & $\Xi$ & 已 & & $\underset{\Xi}{\Xi}$ & Е & $\begin{array}{l}\bar{\Xi} \\
\bar{\Xi}\end{array}$ & & 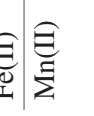 & छ & & & $\left|\begin{array}{l}\Xi \\
z\end{array}\right|$ & है \\
\hline
\end{tabular}




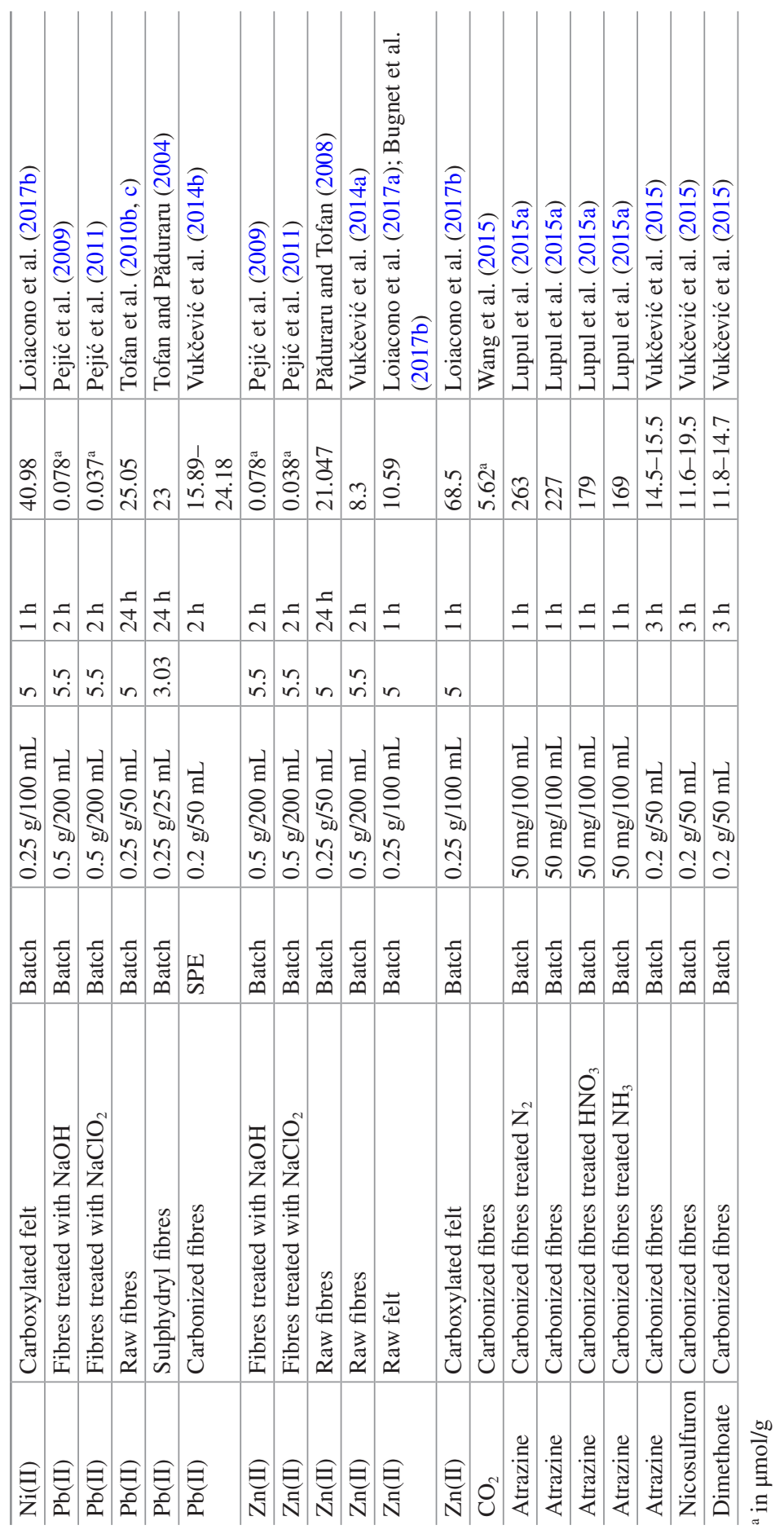


hemp-based material; (ii) the experimental conditions should be chosen to simulate real wastewater containing metals; (iii) much work is necessary to demonstrate the possibilities on an industrial scale using real wastewaters and discharge waters.

\section{References}

Ahmed MJ (2016) Preparation of activated carbons from date (Phoenix dactylifera L.) palm stones and application for wastewater treatments. Rev Process Safety Environ Protection 102:168 182. https://doi.org/10.1016/j.psep.2016.03.010

Amaducci S (2005) Hemp production in Italy. J Ind Hemp 10:109-115

Amaducci S, Gusovious HJ (2010) Hemp - cultivation, extraction and processing. In: Müssig $\mathrm{J}$ (ed) Industrial applications of natural fibres: structure, properties and technical applications. Willey, Chichester, pp 85-135. https://doi.org/10.1002/9780470660324.ch5

Amaducci S, Scordia D, Liu FH, Zhang Q, Guo H, Testa G, Cosentino SL (2015) Key cultivation techniques for hemp in Europe and China. Ind Crops Products 68:2-16. https://doi. org/10.1016/j.indcrop.2014.06.041

Anastopoulos I, Kyzas GZ (2015) Composts as biosorbents for decontamination of various pollutants: a review. Water Air Soil Pollut 226, Article number: 61. https://doi.org/10.1007/ s11270-015-2345-2.

Anastopoulos I, Karamesouti M, Mitropoulos AC, Kyzas GZ (2017a) A review for coffee adsorbents. J Mol Liq 229:555-565. https://doi.org/10.1016/j.molliq.2016.12.096

Anastopoulos I, Bhatnagar A, Bikiaris DN, Kyzas GZ (2017b) Chitin adsorbents for toxic metals: a review. Int J Mol Sci 18:114. https://doi.org/10.3390/ijms18010114

Ayangbenro AS, Babalola OO (2017) A new strategy for heavy metal polluted environments: a review of microbial biosorbents. Int J Environ Res Public Health: 14, Article number: 94. https://doi.org/10.3390/ijerph14010094.

Babel S, Kurniawan TA (2003) Low-cost adsorbents for heavy metals uptake from contaminated water: a review. J Hazard Mater 97:219-243. https://doi.org/10.1016/S0304-3894(02)00263-7

Balintova M, Holub M, Stevulova N, Cigasova J, Tesarcikova M (2014) Sorption in acidic environment - biosorbents in comparison with commercial adsorbents. Chem Eng Transac 39:625630. https://doi.org/10.3303/CET1439105

Berefield LD, Judkins JF, Weand BL (1982) Process chemistry for water and wastewater treatment. Prentice-Hall, Upper Saddle River, 510 p

Bismarck A, Mishra S, Lampke T (2005) Plant fibers as reinforcement for green composites. In: Mohanty AK, Misra M, Drzal LT (eds) Natural fibers, biopolymers, and biocomposites. CRC Press, Boca Raton, pp 37-108

Blackburn RS (2004) Natural polysaccharides and their interactions with dye molecules: applications in effluent treatment. Environ Sci Technol 38:4905-4909. https://doi.org/10.1021/ es049972n

Bono P, le Duc A, Lozachmeur M, Day A (2015) Materials: new fields of research and development for the valorization of technical plant fibres (flax fiber and hemp). OCL Oilseeds \& fats Crops and Lipids. EDP Sciences 22:1-11. https://doi.org/10.1051/ocl/2015041

Bouloc P (2013) Hemp: industrial production and uses. CABI, Oxfordshire, $312 \mathrm{p}$

Bugnet J, Morin-Crini N, Cosentino C, Chanet G, Winterton P, Crini G (2017a) Hemp decontamination of poly-metallic aqueous solutions. Environ Eng Manag J 16:535-542

Bugnet J, Morin-Crini N, Chanet G, Cosentino C, Crini G (2017b) Du chanvre pour dépolluer des eaux polycontaminées en métaux (in French). Morin-Crini G, Crini G (eds), Besançon: PUFC, Chapter XI, pp 323-340

Cassano R, Trombino S, Ferrarelli T, Nicoletta FP, Mauro MV, Giraldi C, Picci N (2013) Hemp fiber (Cannabis sativa L.) derivatives with antibacterial and chelating properties. Cellulose 20:547-557. https://doi.org/10.1007/s10570-012-9804-3 
Citterio S, Santagostino A, Fumagalli P, Prato N, Ranalli P, Sgorbati S (2003) Heavy metal tolerance and accumulation of $\mathrm{Cd}, \mathrm{Cr}$ and $\mathrm{Ni}$ by Cannabis sativa L. Plant Soil 256:243-252. https:// doi.org/10.1023/A:1026113905129.

Cooney DO (1999) Adsorption design for wastewater treatment. Boca Raton: Lewis Publishers, $208 \mathrm{p}$

Crini G (2005) Recent developments in polysaccharide-based materials used as adsorbents in wastewater treatment. Prog Polym Sci 30:38-70. https://doi.org/10.1016/j.progpolymsci.2004.11.002

Crini G (2006) Non-conventional low-cost adsorbents for dye removal. Bioresour Technol 97:1061-1085. https://doi.org/10.1016/j.biortech.2005.05.001

Crini G, Badot PM (2008) Application of chitosan, a natural aminopolysaccharide, for dye removal from aqueous solutions by adsorption processes using batch studies: a review of recent literature. Prog Polym Sci 33:399-447. https://doi.org/10.1016/j.progpolymsci.2007.11.001

Crini G, Badot PM (eds) (2010) Sorption processes and pollution. Besançon: PUFC, 2010, $489 \mathrm{p}$

Dąbrowski A (2001) Adsorption - from theory to practice. Adv Colloid Int Sci 93:135-224

Dabbagh R, Sharifipoor S, Keshtkar A, Vafajoo L (2016) Removal of zinc (II) from synthetic effluent using seaweeds: a review of modeling of fixed-bed columns. Des Water Treatment 57:24509-24518. https://doi.org/10.1080/19443994.2016.1141324

Derbyshire F, Jagtoyen M, Andrews R, Rao A, Martin-Gullon I, Grulke E (2001) Carbon materials in environmental applications. In: Radovic LR (ed) Chemistry and physics of carbon. Marcel Dekker, New York, vol 27, pp 1-66

De Gisi S, Lofrano G, Grassi M, Notarnicola M (2016) Characteristics and adsorption capacities of low-cost sorbents for wastewater treatment: a review. Sustain Mater Technol 9:10-40. https:// doi.org/10.1016/j.susmat.2016.06.002

Dhankhar R, Hooda A (2011) Fungal biosorption - an alternative to meet the challenges of heavy metal pollution in aqueous solutions. Environ Technol 32(5):467-491. https://doi.org/10.1080 /09593330.2011.572922

Di Candilo M, Bonatti PM, Guidetti C, Focher B, Grippo C, Tamburini E, Mastromei G (2009) Effects of selected pectinolytic bacterial strains on water-retting of hemp and fibre properties. J Appl Microbiol 108:194-203. https://doi.org/10.1111/j.1365-2672.2009.04409.x

Dulman V, Cucu-Man SM (2010) Chapter 9: Wood sawdust, tree bark and wood chips: waste lignocellulosic materials for dye removal. In: Crini G, Badot PM (eds) Sorption processes and pollution. PUFC, Besançon, pp 233-269

Faruk O, Bledzki A, Fink HP, Sain M (2012) Biocomposites reinforced with natural fibers: 20002010. Prog Polym Sci 37:1552-1596. https://doi.org/10.1016/j.progpolymsci.2012.04.003

Fomina M, Gadd GM (2014) Biosorption: current perspectives on concept, definition and application. Bioresour Technol 160:3-14. https://doi.org/10.1016/j.biortech.2013.12.102

George M, Mussone PG, Bressler DC (2015) Modification of the cellulosic component of hemp fibres using sulfonic acid derivatives: surface and thermal characterization. Carbohydr Polym 134:230-239. https://doi.org/10.1016/j.carbpol.2015.07.096

Gorska M, Hubicki Z, Wojcik G, Rusek P (2014) Biosorption. An environmentally friendly method for removal and recovery of precious metals. Przemysl Chemiczny 93:1750-1753

Haroon M, Wang L, Yu HJ, Abbasi NM, Zain-ul-Abdin SM, Khan RU, Ullah RS, Chen Q, Wu JL (2016) Chemical modification of starch and its application as an adsorbent material. RSC Adv 6:78264-78285. https://doi.org/10.1039/c6ra16795k

He J, Chen JP (2014) A comprehensive review on biosorption of heavy metals by algal biomass: materials, performances, chemistry. and modeling simulation tools Bioresour Technol 160:6778. https://doi.org/10.1016/j.biortech.2014.01.068

Ho YS, Porter JF, McKay G (2002) Equilibrium isotherm studies for the sorption of divalent metal ions onto peat: copper, nickel and lead single component systems. Water Air Soil Pollut $141: 1-33$

Hubbe MA, Hasan SH, Ducoste JJ (2011) Cellulosic substrates for removal of pollutants from aqueous systems: a review. 1 Metals Bioresour 6:2161-U2914 
Ingrao C, Lo Giudice A, Bacenetti J, Tricase C, Dotelli G, Fiala M, Siracusa V, Mbohwa C (2015) Energy and environmental assessment of industrial hemp for building applications: a review. Renew Sust Energ Rev 51:29-42. https://doi.org/10.1016/j.rser.2015.06.002

Keijsers ERP, Y1lmaz G, van Dam JEG (2013) The cellulose resource matrix. Carbohydr Polym 93:9-21. https://doi.org/10.1016/j.carbpol.2012.08.110

Khalaf MN (2016) Green polymers and environmental pollution control. Oakville: CRC Press; Apple Academic Press, Inc, $436 \mathrm{p}$

Kostić MM, Skundric PD, Milosavljevic S (2003) Hemp is coming back (in Serbia). Tekstilna Industrija 51:9-16

Kostić MM, Pejić BM, Skundric PD (2008) Quality of chemically modified hemp fibres. Bioresour Technol 99:94-99. https://doi.org/10.1016/j.biortech.2006.11.050

Kostić MM, Pejić BM, Asanovic KA, Aleksic VM, Skundric PD (2010) Effect of hemicelluloses and lignin on the sorption and electric properties of hemp fibres. Ind Crops Products 32:169174. https://doi.org/10.1016/j.indcrop.2010.04.014

Kostić M, Vukčević M, Pejić B, Kalijadis A (2014) Hemp fibers: old fibers - new applications. In: Ibrahim M, Mondal M (eds) Textiles: history, properties and performance and applications. Nova Science Publishers, Inc, New York, pp 399-446

Kumar KS, Dahms HU, Won EJ, Lee JS, Shin KH (2015) Microalgae - a promising tool for heavy metal remediation. Ecotoxicol Environ Safety 113:329-352. https://doi.org/10.1016/j. ecoenv.2014.12.019

Kumar R, Sharma RK, Singh AP (2017) Cellulose based grafted biosorbents - journey from lignocellulose biomass to toxic metal ions sorption applications - a review. J Mol Liq 232:62-93. https://doi.org/10.1016/j.molliq.2017.02.050

Kyzas GZ, Kostoglou M (2014) Green adsorbents for wastewaters: a critical review. Materials 7:333-364. https://doi.org/10.3390/ma7010333

Kyzas GZ, Terzopoulou Z, Nikolaidis V, Alexopoulou E, Bikiaris DN (2015) Low-cost hemp biomaterials for nickel ions removal from aqueous solutions. J Mol Liq 209:209-218. https://doi. org/10.1016/j.molliq.2015.05.060

Le Troëdec M, Rachini A, Peyratout C, Rossignol S, Max E, Kaftan O, Fery A, Smith A (2011) Influence of chemical treatments on adhesion properties of hemp fibres. J Colloid Int Sci 356:303-310. https://doi.org/10.1016/j.jcis.2010.12.066

Li WW, Yu HQ (2014) Insight into the roles of microbial extracellular polymer substances in metal biosorption. Bioresour Technol 160:15-23. https://doi.org/10.1016/j.biortech.2013.11.074

Liberalato D (2003) Prospect of hemp utilization in the European textile industry. Agroindustria 2/3:147-148

Liu DHF, Liptak BG (eds) (2000) Wastewater treatment. CRC Press

Loiacono S, Morin-Crini N, Cosentino C, Torri G, Chanet G, Winterton P, Crini G (2017a) Simultaneous removal of $\mathrm{Cd}, \mathrm{Co}, \mathrm{Cu}, \mathrm{Mn}, \mathrm{Ni}$ and $\mathrm{Zn}$ from synthetic solutions on a hemp-based felt: experimental design. J Appl Polym Sci 134:1-11. https://doi.org/10.1002/app.44422

Loiacono S, Crini G, Martel B, Chanet G, Cosentino C, Raschetti M, Placet V, Torri G, MorinCrini N (2017b) Simultaneous removal of Cd, Co, Cu, Mn, Ni and Zn from synthetic solutions on a hemp-based felt. 2: chemical modification. J Appl Polym Sci 134:1-16. https://doi. org/10.1002/app.45138

Loiacono S, Morin-Crini G, Cosentino C, Chanet G, Winterton P, Torri G, Crini G (2017c) La canapa: un material interessante per il trattamento delle acque contaminate da metalli (in Italian). Chimica e Industria 2:8-12. https://doi.org/10.17374/CI.2017.99.2

Lupul I, Yperman J, Carleer R, Gryglewicz G (2015a) Adsorption of atrazine on hemp stem-based activated carbons with different surface chemistry. Adsorption J Int Adsorption Soc 21:489498. https://doi.org/10.1007/s10450-015-9689-1

Lupul I, Yperman J, Carleer R, Gryglewicz G (2015b) Tailoring of porous texture of hemp stembased activated carbon produced by phosphoric acid activation in steam atmosphere. J Porous Mat 22:283-289. https://doi.org/10.1007/s10934-014-9894-4 
Manes M (1998) Activated carbon adsorption fundamentals. In: Meyers RA (ed) Encyclopedia of environmental analysis and remediation, vol 1. Wiley, New York, pp 26-68

McKay G (1996) Use of adsorbents for the removal of pollutants from wastewaters. CRC Press, Boca Raton, 208 p

McKay G, Al Duri B (1989) Prediction of multicomponent adsorption equilibrium data using empirical correlations. Chem Eng J 41:9-23

Michalak I, Chojnacka K, Witek-Krowiak A (2013) State of the art for the biosorption process- a review. Appl Biochem Biotechnol 170:1389-1416. https://doi.org/10.1007/s12010-013-0269-0

Milanovic J, Kostic M, Milanovic P, Skundric P (2012) Influence of TEMPO-mediated oxidation on properties of hemp fibres. Ind Eng Chem Res 51:9750-9759. https://doi.org/10.1021/ ie300713x

More TT, Yadav JSS, Yan S, Tyagi RD, Surampalli RY (2014) Extracellular polymeric substances of bacteria and their potential environmental applications. J Environ Management 144:1-25. https://doi.org/10.1016/j.jenvman.2014.05.010

Morin-Crini N, Crini G (2013) Environmental applications of water-insoluble $\beta$-cyclodextrinepichlorohydrin polymers. Prog Polym Sci 38:344-368. https://doi.org/10.1016/j. progpolymsci.2012.06.005

Mudhoo A, Garg VK, Wang SB (2012) Removal of heavy metals by biosorption. Environ Chem Lett 10:109-117. https://doi.org/10.1007/s10311-011-0342-2

Muya FN, Sunday CE, Baker P, Iwuoha E (2016) Environmental remediation of heavy metal ions from aqueous solution through hydrogel adsorption: a critical review. Water Sci Technol 73:983-992. https://doi.org/10.2166/wst.2015.567

Nastaj J, Przewlocka A (2014) Removal of heavy metal ions from aqueous solutions on alginates. Equilibrium and kinetics. Przemysl Chemiczny 93:1543-1547

Novoselova LY, Sirotkina EE (2008) Peat-based sorbents for the purification of contaminated environments: a review. Solid Fuel Chem 42:251-262. https://doi.org/10.3103/S0361521908040125

Okenicova L, Zemberyova M, Prochazkova S (2016) Biosorbents for solid-phase extraction of toxic elements in waters. Environ Chem Lett 14:67-77. https://doi.org/10.1007/s10311-015-0539-x

Oliveira LS, Franca AS (2008) Low cost adsorbents from agro-food wastes. In: Columbus F (ed) Food science and technology: new research. Nova Publishers, New York, pp 1-39

Pacaphol K, Aht-Ong D (2017) Preparation of hemp nanofibers from agricultural waste by mechanical defibrillation in water. J Cleaner Production 142:1283-1295. https://doi.org/10.1016/j. jclepro.2016.09.008

Păduraru C, Tofan L (2002) Equilibrium studies for the sorption of metal ions onto hemp. Cellulose Chem Technol 36:375-380

Păduraru C, Tofan L (2008) Investigations on the possibility of natural hemp fibres use for $\mathrm{Zn}$ (II) removal from wastewaters. Environ Eng Manag J 7:687-693

Pejić BM, Kostić MM, Skundric PD, Praskalo JZ (2008) The effects of hemicelluloses and lignin removal on water uptake behavior of hemp fibres. Bioresour Technol 99:7152-7159. https:// doi.org/10.1016/j.biortech.2007.12.073

Pejić BM, Vukčević MM, Kostić MP, Skundric PD (2009) Biosorption of heavy metal ions from aqueous solutions by short hemp fibres: effect of chemical composition. J Hazard Mater 164:146-153. https://doi.org/10.1016/j.jhazmat.2008.07.139

Pejić BM, Vukčević MM, Pajić-Lijaković ID, Laušević MD, Kostić MM (2011) Mathematical modeling of heavy metal ions $\left(\mathrm{Cd}^{2+}, \mathrm{Zn}^{2+}\right.$ and $\left.\mathrm{Pb}^{2+}\right)$ biosorption by chemically modified short hemp fibres. Chem Eng J 172:354-360. https://doi.org/10.1016/j.cej.2011.06.016

Placet V, Meteau J, Froehly L, Salut R, Boubakar ML (2014) Investigation of the internal structure of hemp fibres using optical coherence tomography and focused ion beam transverse cutting. J Mater Sci 49:8317-8327. https://doi.org/10.1007/s10853-014-8540-5

Placet V, Day A, Beaugrand J (2017) The influence of unintended field retting on the physicochemical and mechanical properties of industrial hemp bast fibres. J Mater Sci 52:5759-5777. https://doi.org/10.1007/s10853-017-0811-5 
Radovic LR, Moreno-Castilla C, Rivera-Utrilla J (2000) Carbon materials as adsorbents in aqueous solutions. Chemistry and Physics of Carbon 27:227-405

Ramakrishna KR, Viraraghavan T (1997) Dye removal using low cost adsorbents. Water Sci Technol 36:189-196. https://doi.org/10.1016/S0273-1223(97)00387-9

Ranalli P (1999) Advances in hemp research. Food Product Press, Binghamton, 272 p. ISBN 9781560228721

Ranalli P, Venturi G (2004) Hemp as a raw material for industrial applications. Euphytica 140:1-6. https://doi.org/10.1007/s10681-004-4749-8

Raval NP, Shah PU, Shah NK (2016) Adsorptive removal of nickel(II) ions from aqueous environment: a review. J Environ Manag 179:1-20. https://doi.org/10.1016/j.jenvman.2016.04.045

Rehman MSU, Rashid N, Saif A, Mahmood T, Han JI (2013) Potential of bioenergy production from industrial hemp (Cannabis sativa): Pakistan perspective. Renew Sust Energ Rev 18:154 164. https://doi.org/10.1016/j.rser.2012.10.019

Rezić I (2013) Cellulosic fibres - Biosorptive materials and indicators of heavy metal pollution. Microchem J 107:63-69

Rosas JM, Bedia J, Rodriguez-Mirasol J, Cordero T (2009) Hemp-derived activated carbon fibres by chemical activation with phosphoric acid. Fuel 88:19-26. https://doi.org/10.1016/j. fuel.2008.08.004

Salentijn EMJ, Zhang Q, Amaducci S, Yang M, Trindade LM (2015) New developments in fiber hemp (Cannabis sativa L.) breeding. Ind Crop Prod 68:32-41. https://doi.org/10.1016/j. indcrop.2014.08.011

Salman M, Athar M, Farooq U (2015) Biosorption of heavy metals from aqueous solutions using indigenous and modified lignocellulosic materials. Rev Environ Sci Biotechnol 14:211-228. https://doi.org/10.1007/s11157-015-9362-x

Shahzad A (2012) Hemp fiber and its composites - a review. J Composite Mat 46:973-986. https:// doi.org/10.1177/002199831143623

Shakya M, Sharma P, Meryem SS, Mahmood Q, Kumar A (2016) Heavy metal removal from industrial wastewater using fungi: uptake mechanism and biochemical aspects. J Environ Eng 142(Special issue):C6015001. https://doi.org/10.1061/(ASCE)EE.1943-7870.0000983

Sharma SK (2015) Green chemistry for dyes removal from wastewater. Scrivener Publishing LLC Wiley, Beverley, 496 p

Sharma SK, Sanghi R (2012) Advances in water treatment and pollution prevention. Springer, Dordrecht, $460 \mathrm{p}$.

Srivastava S, Agrawal SB, Mondal MK (2015) A review on progress of heavy metal removal using adsorbents of microbial and plant origin. Environ Sci Pollut Res 22:15386-15415. https://doi. org/10.1007/s11356-015-5278-9

Streat M, Patrick JW, Perez MJC (1995) Sorption of phenol and para-chlorophenol from water using conventional and novel activated carbons. Water Res 29:467-472. https://doi. org/10.1016/0043-1354(94)00187-C

Stevulova N, Cigasova J, Estokova A, Terpakova E, Geffert A, Kacik F, Singovszka E, Holub M (2014) Properties and characterization of chemically modified hemp hurds. Materials 7:81318150. https://doi.org/10.3390/ma7128131

Suba V, Rathika G (2016) Novel adsorbents for the removal of dyes and metals from aqueous solution - a review. J Adv Phys 5:277-294. https://doi.org/10.1166/jap.2016.1269

Sun JJ, Gao JM, Hao XM, Cui XY, Ma T Yang Y (2013) Effects of air-phosphoric acid activation on pore structure and adsorption property of mesoporous carbon from hemp stem. Book Series: Advanced materials research 821-822:41-46. https://doi.org/10.4028/www.scientific. net/AMR.821-822.41

Tapia-Orozco N, Ibarra-Cabrera R, Tecante A, Gimeno M, Parra R, Garcia-Arrazola R (2016) Removal strategies for endocrine disrupting chemicals using cellulose-based materials as adsorbents: a review. J Environ Chem Eng 4:3122-3142. https://doi.org/10.1016/j.jece.2016.06.025

Tien C (1994) Adsorption calculations and modeling. Butterworth-Heinemann College, Newton, $288 \mathrm{p}$

Tofan L, Păduraru C (1999) Removal of copper(II) ions in traces from waste waters by sorption on hemp modified with $\alpha$-benzoinoxime. J Balkan Ecology 2:106-112 
Tofan L, Păduraru C (2000) The hemp - a new fibrous natural unconventional sorbent. Buletinul Institului Politechnic Iasi, series of chemie and chemical engineering. Tome XLVI (L) fascicule 3-4:113-118

Tofan L, Păduraru C (2004) Sorption studies of Ag(I), Cd(II) and Pb(II) ions on sulphydryl hemp fibres. Croat Chem Acta 77:581-586

Tofan L, Gherasim O, Păduraru C, Toma O (2001a) Hemp impregnated with $\alpha$-benzoinoxime for removal of copper (II) pollutant ions. Scientific Annals of AlI Cuza University of Iasi Section II a Genetics and Molecular Biology, Tome II, pp 81-85

Tofan L, Păduraru C, Toma O (2001b) Hemp fibres impregnated with alizarine S as unconventional material for $\mathrm{Cr}$ (III) ions in technological systems. Scientific Annals of the State University of Moldavia Chisinau, pp 204-208

Tofan L, Păduraru C, Volf I (2009) Concentration of cadmium (II) trace amounts from large volumes of aqueous samples of chemically modified hemp fibres. Scientific Papers J Agron Ser 52:506-511

Tofan L, Păduraru C, Volf I (2010a) Comparative study concerning the retention thermodynamics of some heavy metal ions on hemp fibres. Buletinul Institului Politechnic Iasi LVI LX:137-145

Tofan L, Păduraru C, Volf I, Balan C (2010b) Kinetic and thermodynamic profile of Pb(II) sorption by untreated hemp fibres. Scientific Papers J Agronomy Ser 53:146-150

Tofan L, Păduraru C, Volf I, Balan C (2010c) Removal of lead(II) from aqueous solution by sorption by on natural hemp fibres. Scientific Papers J Agronomy Ser 53:150-153

Tofan L, Teodosiu C, Păduraru C, Wenkert R (2013) Cobalt(II) removal from aqueous solutions by natural hemp fibres: batch and fixed-bed columns studies. Appl Surface Sci 285:33-39. https:// doi.org/10.1016/j.apsusc.2013.06.151

Tofan L, Păduraru C, Teodosiu C, Toma O (2015) Fixed bed columns study on the removal of chromium (III) ions from aqueous solutions by hemp fibres with improved sorption performance. Cellulose Chem Technol 49:219-229

Tofan L, Păduraru C, Toma O (2016a) Zinc remediation of aqueous solutions by natural hemp fibres: batch desorption/regeneration study. Des Water Treatment 57:12644-12652. https://doi. org/10.1080/19443994.2015.1052566

Tofan L, Wenkert R, Păduraru C (2016b) Natural and waste materials as green sorbents for Cd(II) removal from aqueous effluents. Environ Eng Manag J 15:1049-1058

Tran VS, Ngo HH, Guo WS, Zhang J, Liang S, Ton-That C, Zhang XB (2015) Typical low cost biosorbents for adsorptive removal of specific organic pollutants from water. Bioresour Technol 182:353-363. https://doi.org/10.1016/j.biortech.2015.02.003

Treybal RE (1987) Mass transfer operations. McGraw-Hill, New York, $800 \mathrm{p}$

Ummartyotin S, Pechyen C (2016) Strategies for development and implementation of bio-based materials as effective renewable resources of energy: a comprehensive review on adsorbent technology. Renew Sust Energ Rev 62:654-664. https://doi.org/10.1016/j.rser.2016.04.066

Vandenbossche M, Jimenez M, Casetta M, Traisnel M (2015) Remediation of heavy metals by biomolecules: a review. Crit Rev Environ Sci Technol 45:1644-1704. https://doi.org/10.1080/ 10643389.2014.966425

Vandenhove H, Van Hees M (2003) Fibre crops as alternative land use for radioactively contaminated arable land. J Environ Radioact 81:131-141. https://doi.org/10.1016/j.jenvrad.2005.01.002

Vijayaraghavan K, Balasubramanian R (2015) Is biosorption suitable for decontamination of metalbearing wastewaters? A critical review on the state-of-the-art of biosorption processes and future directions. J Environ Manag 160:283-296. https://doi.org/10.1016/j.jenvman.2015.06.030

Volesky B (1990) Biosorption of metals. CRC Press, Boca Raton, 408 p

Volesky B (2004) Sorption and biosorption. BV-Sorbex, Inc, Montreal, $316 \mathrm{p}$

Vukčević M, Kalijadis A, Radisic M, Pejić B, Kostić M, Laušević Z, Laušević M (2012) Application of carbonized hemp fibres as a new solid-phase extraction sorbent for analysis of pesticides in water samples. Chem Eng J 211:224-232. https://doi.org/10.1016/j.cej.2012.09.059

Vukčević M, Pejić B, Laušević M, Pajić-Lijaković I, Kostić M (2014a) Influence of chemically modified short hemp fiber structure on biosorption process of $\mathrm{Zn}^{2+}$ ions from waste water. Fibres Polymers 15:687-697. https://doi.org/10.1007/s12221-014-0687-9 
Vukčević M, Pejić B, Kalijadis A, Pajić-Lijaković I, Kostić M, Laušević Z, Laušević M (2014b) Carbon materials from waste short hemp fibres as a sorbent for heavy metal ions - mathematical modeling of sorbent structure and ions transport. Chem Eng J 235:284-292. https://doi. org/10.1016/j.cej.2013.09.047

Vukčević M, Kalijadis AM, Vasiljevic TM, Babic BM, Laušević ZV, Laušević MD (2015) Production of activated carbon derived from waste hemp (Cannabis sativa) fibres and its performance in pesticide adsorption. Microporous Mesoporous Mater 214:156-165. https://doi. org/10.1016/j.micromeso.2015.05.012

Wang Y, Yang R, Li M, Zhao ZJ (2015) Hydrothermal preparation of highly porous carbon spheres from hemp (Cannabis sativa L.) stem hemicellulose for use in energy-related applications. Ind Crop Prod 65:216-226. https://doi.org/10.1016/j.indcrop.2014.12.008

Wase J, Forster C (1997) Biosorbents for metal ions. Taylor \& Francis, Bristol, 249 p

Westholm LJ, Repo E, Sillanpää M (2014) Filter materials for metal removal from mine drainagea review. Environ Sci Pollut Res 21:9109-9128. https://doi.org/10.1007/s11356-014-2903-y

Williams PT, Reed AR (2003) Pre-formed activated carbon matting derived from the pyrolysis of biomass natural fiber textile waste. J Anal Appl Pyrolysis 70:563-577

Williams PT, Reed AR (2004) High grade activated carbon matting derived from the chemical activation and pyrolysis of natural fibre textile waste. J Anal Appl Pyrolysis 71:971-986

Yang TR (2003) Adsorbents: fundamentals and applications. Wiley-Interscience, Hoboken, $424 \mathrm{p}$

Yang R, Liu GQ, Xu XH, Li M, Zhang JC, Hao XM (2011) Surface texture, chemistry and adsorption properties of acid blue 9 of hemp (Cannabis sativa L.) bast-based activated carbon fibres prepared by phosphoric acid activation. Biomass Bioenergy 35:437-445. https://doi. org/10.1016/j.biombioe.2010.08.061

Yang R, Liu GQ, Li M, Zhang JC, Hao XM (2012) Preparation and $\mathrm{N}_{2}, \mathrm{CO}_{2}$ and $\mathrm{H}_{2}$ adsorption of super activated carbon derived from biomass source hemp (Cannabis sativa $\mathrm{L}$.) stem. Microporous Mesoporous Mat 158:108-116. https://doi.org/10.1016/j.micromeso.2012.03.004

Zhang L, Zeng Y, Cheng Z (2016) Removal of heavy metal ions using chitosan and modified chitosan: a review. J Mol Liq 214:175-191. https://doi.org/10.1016/j.molliq.2015.12.013

Zhao XJ, Zhou ZQ (2016) Synthesis and applications of pectin-based nanomaterials. Current Nanosci 12:103-109. https://doi.org/10.2174/1573413711666150818224020

Zhao MH, Xu Y, Zhang CS, Rong HW, Zeng GM (2016) New trends in removing heavy metals from wastewater. Appl Microbiol Biotechnol 100:6509-6518. https://doi.org/10.1007/ s00253-016-7646-X

Zou XQ, El Fallah J, Goupil JM, Zhu GS, Valtchev V, Mintova S (2012) Green removal of aromatic organic pollutants from aqueous solutions with a zeolite-hemp composite. RSC Adv 2:3115-3122. https://doi.org/10.1039/c2ra01176j 